\title{
ABOLISHING THE PERSONAL INJURY TORT SYSTEM: THE NEW ZEALAND EXPERIENCE
}

\author{
GEOFFREY W. R. PALMER*
}

The position advanced by Mr. Laycraft in his earlier article in this volume is one side of what is becoming an ever deepening controversy. In this article Professor Palmer attacks Mr. Laycraft's thesis and puts forward some justifications for root and branch change in the field of compensation for personal injuries. A plethora of plans has been suggested in recent years aimed at fundamentally altering compensation for personal injury. It has become evident that there are basic political difficulties involved in implementing these plans. The author, who was retained by the New Zealand Government to draft a White Paper on Personal Injury in New Zealand in 1969, discusses the political struggle which is now reaching a conclusion in New Zealand concerning a very radical proposal made by a New Zealand Royal Commis. sion in 1967.

\section{INTRODUCTION}

The dual purposes of this article sit uneasily together. First, it is necessary to fulfill my commitment to the editor of the Alberta Law Review by attempting to question, and if possible, refute the orthodoxies in favour of the automobile tort system presented by Mr. Laycraft in the preceding article. At the same time I feel an obligation to report upon recent developments on the New Zealand compensation scene which promise to shatter the orthodoxies of the common law but which have been little commented upon and are little known abroad.

The object of this article is to demonstrate that the entire common law system for compensating personal injury losses should be abolished. The system should be abolished for all accidents, not merely for those connected with automobiles. Such a suggestion is not new and as an abstract proposition seems to be thoroughly justified by the arguments.

It is not a sufficient answer to Mr. Laycraft, however, to say that the automobile tort system should be done away with. It is necessary to have a replacement. The nature and quality of the replacement is an essential item in any equation pitting the fault system against its competitors. Of course, many plans have been suggested in recent years, some aimed at fundamentally altering compensation for personal injury and others concerned to tinker with it here and there with the underlying aim of shoring up the edifice. Few examples of the first type of plan have come close to being implemented. But a New Zealand scheme with bold features will be enacted this year.

This paper will discuss in detail the features of the New Zealand plan. Such a presentation, it is hoped, will provide a touchstone against which Mr. Laycraft's timid response to the demands for change

\footnotetext{
- B.A., LLB. (Victoria University of Wellington), J.D. (Chicago). Assistant Professor of Law, University of Iowa, Iowa City. Iowa, U.S.A. The writer is grateful to his colleagues Professors William Buss, David Baldus and Alan Widiss for having read and commented upon various drafts of this paper. In 1969 the author was retained by the New Zealand Government to draft the White Paper on Personal Injury in New Zealand which is referred to herein.
} 
can be measured. At first glance there appears to be little justification for considering social change in New Zealand as a benchmark for Canada. There are considerable differences between the Canadian and New Zealand political and social environments and one ought to be hesitant in urging Canadians to take as their own a solution worked out for another society. Yet in the field of compensation for personal injury the fundamental problems are similar. New Zealand and most of the Canadian provinces share a common law heritage. There is a widespread practice for common law countries of the Commonwealth to examine each other's efforts at law reform and often borrow from one another. There are more specific connections. Two Canadian sources exerted considerable influence over the shape of the New Zealand scheme. The Royal Commission on Compensation for Personal Injury in New Zealand, which recommended a comprehensive no-fault system for compensating personal injury in 1967, travelled to Canada and the Commissioners were much impressed with the Canadian method of administering workmen's compensation, especially as they observed it in Ontario. The recommendations concerning administration of their scheme relied almost entirely on the Ontario model. Secondly, the nature of the scheme proposed bears the imprimatur of Professor T. G. Ison of Queen's University and his book, The Forensic Lottery. It is not without irony that, so far, these two sources of wisdom concerning personal injury compensation have been more influential in promoting change in New Zealand than in Canada.

There is another thread to the New Zealand experience which will be reviewed-the political problems of implementing compensation plans. The conclusions that can be drawn from this part of the discussion are tentative, but the material is worth presenting because there has been very little discussion in the literature about the problems of implementing compensation plans. Such plans, especially those of the more radical variety, are likely to be politically controversial everywhere. The more comprehensive the plan the wider the range of interests which stand to be hurt by its implementation. Lawyers and insurance companies have, or think they have, an important stake in the common law status quo. These groups and others which tend to oppose root and branch reform of personal injury compensation are important and influential sources of political power in most Western societies. When faced with strong opposition from such groups, politicians feel that they are running substantial political risks if they move to overthrow existing compensation arrangements. The struggle in New Zealand has been continuing for three years and the fundamental decisions to advance have been made. They were not decisions easily arrived at. Therefore, a descriptive analysis of the manner in which the New Zealand political process dealt with the personal injury challenge may be interesting to others.

Since Mr. Laycraft's position will be attacked sometimes directly and sometimes by implication throughout the article let me make a general comment about it now.

Mr. Laycraft observes that "the social problems inherent in a just and complete system of reparation for victims of automobile 
accidents have been of increasing concern" of late, ${ }^{1}$ a proposition with which it is difficult to disagree. After a consideration of proposals made in Western Canada for changing the present systems of compensating injuries arising from automobile accidents, Laycraft concludes the tort system in Alberta ought to be left substantially intact, although it should be improved by the abolition of Alberta's guest statute $^{2}$ and introduction of compulsory insurance. ${ }^{3}$ Despite $\mathrm{Mr}$. Laycraft's admission that there are "social problems" involved in any discussion of an automobile reparations system he entirely fails to analyse what those problems are or to deal with them. This omission seems to lead him to advocate a reparation system which is, I hope to demonstrate, neither complete nor just. In short, Mr. Laycraft's conclusions on the merits of the present system are just plain wrong and his assertion that a no fault system would be "distasteful" is unpersuasive. An examination of the desirable social targets of a personal injury reparation system, targets which are neglected by Mr. Laycraft, ought to demonstrate how inadequate is his position.

In reaching his conclusions, Mr. Laycraft neglected to refer to much of the most important writing on reform of the personal injury compensation system. ${ }^{4}$ In particular, I find it incomprehensible that a Canadian writing on this topic should make no reference to the writings of Professor Ison. ${ }^{5}$ Recent developments in the United States, especially in New York and Massachusetts, should also have given Mr. Laycraft cause to pause, ${ }^{6}$ not to mention the revolutionary proposals made by the New Zealand Royal Commission. ${ }^{7}$

One other matter might be disposed of now to avoid saying anything about it later. The recent Report of the Legislative Committee on Automobile Insurance presented to the Legislative Assembly of Alberta, which made recommendations similar to the changes advocated by $\mathrm{Mr}$. Laycraft, is to my mind an uninformative, uninspired

\footnotetext{
' Laycraft, Reforming the Automobile Tort System. (1970) 9 Alta. Law Rev. 22. This analysis of Mr. Lay. craft's article contains no discussion of the problems associated with compensating property damage resulting from automobile accidents.

2 Highway Traffic Act, S. A. 1967, c.30, s. 211. See Laycraft, supra, n. 1 at 40 et seq.

${ }^{3}$ Laycraft, supra, n. 1 at 42 et seq.

- Calabresi, The Costs of Accidents (1970); Elliott and Street, Road Accidents (1968); Blum and Kalven Public Law Perspectives on a Private Law Problem (1965); Conrad, et al., Automobile Accident Costs and Payments (1964); Jolowicz, Liability for Accidents. (1968) 26 Camb. I.J. 50; Blum and Kalven, A Stop-Gap Plan For Compensating Auto Accident Victims, [1968] Ins. L. J. 661: Kalven, A Schema of Alternatives to the Present Auto Accident Tort System. (1968) I Conn. L. Rev. 33; Franklin, Replacing the Negligence Lottery: Compensation and Selective Reimbursement, (1967) 53 Va. L. Rev. 764; Keeton, Is There a Place For Neglizence in Modern Tort Law?, (1967) 53 Va. L. Rev. 886; James, An Eualuation of the Fault Concept, (1965) 32 Tenn. L. Kev. 394. An English book recently published is Atiyah. Accidents, Compensation and the Law (1970). Recent developments in Canada have been summarized by Professor Linden in Department of Transportation Automobile Insurance and Compensation Study, Comparative Studies in Automobile Accident Compensation, "Automobile Insurance Breakthrough in Canada," 149 (1970). For a suggestion by a former Canadian judge that the negligence system is an inadequate means of compensation for automobile accidents see McRuer, "The Motor Car and The Law" in Linden (ed)., Studies in Canadian Tort Law, 303 (1968).

s Ison, The Forensic Lottery (1967). Ison, Comment, Highway Accidents and the Demise of Tort Liability, (1969) 47 Can. Bar Rev. 304; Ison, Tort Liability and Social Insurance, (1969) 19 U.T.L.J. 614.

- State of New York Insurance Department, Automobile Insurance: For Whose Benefit? (1970). For the text of the no fault legislation introduced into the New York Assembly under Number 6133, see New York Law Journal, March 16, 1970, at 1, col. 4. A no fault bill became law in Massachusetts in 1970. See Commonwealth of Massachusetts, Chapter 670, S.F. 1580, "An Act providing for compulsory persona] injury protection for all registered motor vehicles, defining such protection, restricting the right to claim damages for pain and suffering in certain actions of tort, regulating further the premium charges for Compulsory Automobile Insurance, and amending certain laws relating thereto." See also bills introduced into the United States Senate by Senator Philip A. Hart, of Michigan, to reform automobile insurance and introduce a no fault system: S 4339, S 4340, S 4341, 116 CONG. REC. 15,260 (daily ed. September 14, 1970).

'Report of Royal Commission of Inquiry, Compensation for Personal Injury in New Zealand (1967).
} 
unconvincing and poorly researched consideration of the automobile accident problem. ${ }^{8}$ The politicians of Alberta may find, in time, that there are adverse political consequences attendant upon a failure to face the basic issues of personal injury compensation. Perhaps it was never contemplated that the Committee undertake a substantial study, but the tinkering the Committee did recommend can hardly be justified without a consideration of the basic purposes of automobile insurance. I suggest that the Government of Alberta devote resources to doing an adequately researched study of the entire personal injury problem. Such a project is essential if rational decisions are to be made in this highly complex and rapidly changing field.

\section{NEWZEALAND'S MALADY ANDCURE}

Since developments in New Zealand figure so prominently in this paper, it might be as well to briefly summarize what has been happening there. New Zealand has long had something of a reputation for progressive social policies and a willingness to experiment with bold reforms, although the fires of innovation do not burn with the intensity they once did, perhaps. It is surprising, however, that prior to the recent burst of activity so little had been done for so long to make order out of the various mismatched arrangements for compensation for personal injury.

The present arrangements which exist in New Zealand grew up independently and are not coordinated with one another. ${ }^{9}$ An injured person can institute a common law action for damages or breach of a statutory duty, and he has the right to a jury trial. The common law action can be pursued for work connected accidents, too. The Workers' Compensation Act, which pays relatively low benefits, is available for those workmen who cannot prove fault. Both remedies can be pursued simultaneously. Insurance for both is compulsory, and is carried by private insurance companies. ${ }^{10}$ The rates are controlled by government regulation.

A compulsory liability insurance scheme has been in force since 1923 for automobile accidents, the premiums being built into the licensing fee. ${ }^{11}$ The owner of a vehicle nominates an insurance company on the license application and the contract of insurance automatically takes effect. There are special provisions to deal with unidentified or uninsured vehicles which cause accidents. ${ }^{12}$ Injured persons who do not have a common law action for damages or a workers' compensation claim can secure a social security benefit. ${ }^{13}$

New Zealand has had a comprehensive social security scheme for the alleviation of various types of hardship since 1935. In New Zealand the term "social security" covers a broad range of social welfare programmes. The basic purpose of the legislation has been to

\footnotetext{
- Report of the Legislative Committee on Automobile Insurance to The Legislative Assembly of Alberta.

- The profile of New Zealand's present arrangements are reviewed in the Government White Paper on the Royal Commission's Report, Personal Injury-A Commentary on the Report of the Royal Commission of Inquiry into Compensation for Personal Injury in New Zealand 26 (1969), presented to the House of Representatives by leave. (hereinafter cited as "White Paper.")

10 Employers Liability Insurance Reg8. 1968, S/R 1968/35 (N.Z.).

1 Transport Act 1962, 8. 82; Transport Amendment Act 1968, s. 19. (N.Z.).

12 White Paper, supra, n.9 at 39.

13 Social Security Act 1964 (N.Z.).
} 
provide "basic assistance at a level which would enable every person to maintain himself against need without undue strain."14 Payments are flat rate payments and most benefits abate where the beneficiary has income in excess of that permitted by the income test. ${ }^{15}$

At the end of 1967 the Royal Commission chaired by $\mathrm{Mr}$. Justice Woodhouse recommended that in place of the existing remedies there should be a comprehensive compensation scheme to embrace road accidents, work accidents and every other sort of injury which was unexpected so far as the injured person is concerned. Incapacity arising from sickness or disease were excluded. It was the injury itself which was to be the focus of attention, not its cause. Fault was irrelevant. The finance for the scheme was to come mainly from the same sources used for the existing arrangements described above. Benefits were to be related to earnings and paid on a periodic basis rather than a lump sum. Insurance companies were to have no part in the administration of the scheme which was to be run by an independent government corporation. The Commission placed much emphasis on the prevention of accidents and the rehabilitation of the injured.

The Report, which has become known as the Woodhouse Report, is a beautifully written, closely researched and highly persuasive document.16 Yet it took some time for the full impact of its proposals to be appreciated. In October 1969 the Government tabled in Parliament a 173-page White Paper which was a systematic analysis of the feasibility of the Commission's proposals resulting from study by top Government officials. ${ }^{17}$ Although the White Paper was published in the form of a commentary rather than as a statement of policy it was clear that government officials thought that the plan was both practicable and desirable.

A Select Parliamentary Committee was established to hear submissions. The Committee reported in November, 1970, and it essentially adopted the recommendations of the Royal Commission for persons in employment and those injured on the road. ${ }^{18}$ Persons not in employment injured other than on the road would not be covered by the scheme. The Committee altered the details of the Commission's blueprint in some interesting ways which will be reviewed later. Cabinet considered the Committee's recommendations and decided to proceed with legislation based on the Committee's Report. It might be added that those not covered by the scheme are likely to be the subject of recommendations of a new Royal Commission which is investigating social security and which will report in 1971.

14 Compensation for Personal Injury in New Zealand, supra, n.7 at para. 207.

is It is interesting to note that the New Zealand Ombudsman. Sir Guy Powles, in submissions to the Royal Commission on Social Security, said that he had, in effect, acted as a Social Security appeals tribunal for the eight years in which the office of Ombudsman has been established in New Zealand. He said that between 1962 and March 31, 1970, he had 716 complaints against decisions of the Social Security Commission. It seemed to him that the Social Security Commission has interpreted the provisions concerning ministerial control and discretionary powers in a manner which wrongly fettered the Social Security Commission's discretion in exercise of some of its powers. The Christchurch Press, May 28, 1970, at 26, col. 1.

16 Compensation for Personal Injury in New Zealand, supra, n. 7.

17 White Paper, supra, n. 9. For a comment see Szakats, Reform of Personal Injury Compensation: The White Paper on the Woodhouse Report, (1970) 4 N.Z.U.L.R. 139.

18 Report of Select Committee on Compensation for Personal Injury in New Zealand-laid on table of House of Representatives (1970). 


\section{THE DEFICIENCIES OF THE COMMONLAW}

The heart of Mr. Laycraft's case rests on his spirited defence of the common law action for negligence. Lawyers are, of course, prone to worship at the shrine of our Lady, the Common Law. It is necessary, however, for lawyers to be capable of analysing the social goals and policies promoted or prevented by the operations of the legal rules with which they are familiar. Such analysis requires a contextual rather than a doctrinal approach. The New Zealand judge who wrote the Royal Commission's Report saw the common law quite differently from Mr. Laycraft. He concluded:

a. The adversary system hinders the rehabilitation of injured persons after accidents and can play no effective part beforehand in preventing them.

b. The fault principle cannot logically be used to justify the common law remedy and is erratic and capricious in operation.

c. The remedy itself produces a complete indemnity for a relatively tiny group of injured persons; something less (often greatly less) for a small group of injured persons; for all the rest it can do nothing.

d. As a system it is cumbersome and inefficient; and it is extravagant in operation to the point of absorbing for administration and other charges as much as $\$ 40$ for every $\$ 60$ paid over to successful claimants.

e. The appropriate objectives of a compensation system are community responsibility, comprehensive entitlement, complete rehabilitation, real compensation and administrative efficiency. The common law falls short of those goals.19

Mr. Laycraft uses considerable space to argue that six alleged weaknesses of the common law are not weaknesses at all. ${ }^{20}$ These arguments will be examined.

\section{Difficulty in Determining Fault}

Mr. Laycraft tries to controvert the conclusion "that it is not possible to determine who was at fault in most automobile accidents."21 Perhaps the determination of fault is not impossible in the vast majority of cases. But it does involve a tremendously expensive, time consuming and complicated process to try and reconstruct what happened in an accident. Not infrequently there are issues of causation which can be as complicated as any problems known to the law. These problems are likely to increase with the greater emphasis which is being placed on psychic injuries these days. The sudden circumstances in which many motor accidents take place must surely make the determination of fault a rather artificial interpretation of events.

The criticism that the fault principle is impossible to apply runs into the argument that there are difficulties in applying the law to many classes of case which come before the courts. ${ }^{22}$ Conflict of evidence in the reconstruction of complicated fact situations is a constant problem in litigation of all sorts. The courts do the best they can. In another sense, however, negligence law cannot be applied according to its own doctrines. Negligence law postulates that the wrong-

19 Compensation for Personal Injury in New Zealand. supra, n.7 at para. 171.

20 Laycraft, supra, n. 1 at 31.32 .

21 Id. at 33-34.

22 On this point 1 agree with Professors Blum and Kalven:

The law can tolerate a goodly margin of error, and the threshold of distortion which this attack on liability for fault must establish before it becomes a persuasive reason for throwing over the system is high. We remain skeptical that the evidentiary aspects of the auto accident are so peculiar as to be set apart from the evidentiary aspects of all other controversies that are brought to law. Blum and Kalven, Public Law Perspectives on a Private Law Problem. supra, n.4 at 9-10.

This conclusion is strenuously resisted by Professor Robert Keeton in his recent book: Keeton, Venturing To Do Justice, 129-131 (1969). 
doer must pay. In a situation where there is widespread liability insurance that objective is frustrated. In any case the fact that negligence law can be applied does not mean that it is an adequate instrument to achieve the desired social goals of accident law. To those goals it simply does not speak.

\section{Delay}

Mr. Laycraft is somewhat misleading on the subject of delay in the common law and entirely overlooks its consequences. He concludes that the problem is by no means as serious as it is often made out to be and that delay is usually "a procedural defect either in the legal system or in the insurance industry." ${ }^{23}$ At this point Mr. Laycraft is saying that delay is caused by administrative inefficiency and not the system itself. That argument is unobjectionable in itself but Mr. Laycraft seems to base it upon an unrelated and erroneous premise that "The mere fact that a claim has not been determined for a considerable period does not mean that it has been unduly delayed." 24 No doubt efficiency on the part of lawyers and courts would enable some part of the present delay to be reduced. But so long as the fault system survives substantial delay is inevitable. As Professor Ison has said "...the basic defects of the system are institutional, not operational, and most of the delay flows inevitably from the processes required to determine fault in each case and to assess lump-sum compensation." 25

Mr. Laycraft correctly points out that under present arrangements damages cannot be fixed until all the medical evidence is available and this generally means waiting until the plaintiff's condition has stabilized. Under the common law lump-sum system of awarding damages the plaintiff gets nothing until the final determination of his claim by the court, or more usually, by settlement. That determination will not be made until the evidence in respect of liability has been appraised. As one writer has remarked, "fault finding is a highly skilled craft that consumes hungrily of intellectual and emotional energy of counsel, client, witnesses and judges."26 Whatever the degree of delay in a particular jurisdiction and there is evidence that in some places it is very considerable indeed, ${ }^{27}$ some substantial delay is part and parcel of present common law compensation arrangements.

The consequences of delay are serious. The accident victims and their families are likely to lose earned income, be unable to meet financial obligations and to have the personal and social lives of themselves and their families severely disrupted. Physical and vocational rehabilitation of the accident victim is likely to be impaired by both the strategic need to maximize the claim until it is settled and the very real anxiety stemming from doubt about what the final outcome will be. Research into accident prevention is impeded because both sides are very close-lipped about the circumstances of the accident until the threat of litigation has receded. In response to these problems all Mr. Laycraft offers is an advanced payments scheme

\footnotetext{
23 Laycraft, supra, n.1 at 33.

24 Id. at 32.

2s Ison, The Forensic Lottery, supra, n.5, at 26.

26 Parsons, Death and Injury on the Roads, (1955) 3 U.W. Austl. L. Rev. 201 at 230.

27 Compensation for Personal Injury in New Zealand, supra, n.7, at para. 107. Department of Transportation, Automobile Insurance and Compensation Study, Auto Claims Accident Litigation, at 26 et seq. (1970).
} 
which might be a palliative but certainly is not a cure so long as fault is retained. ${ }^{28}$

On the subject of delay in the processes of the common law the New Zealand Royal Commission commented:

We think it would soon become entirely unacceptable if it were realised that such a laggard achievement could be replaced by a modern system able to provide immediate financial assistance for all who might be injured as an installment of compensation that in every way was fair and adequate. ${ }^{29}$

\section{The False Morality of Negligence}

Mr. Laycraft boldly 'asserts that "the citizens of Alberta would find exceedingly distasteful the sight of drivers being compensated for their own negligence from the funds created by the contributions of all."30 He argues that "the basic problem reasserts itself that innocent and guilty are treated as equal in merit. It is this moral conflict which is the foundation of the debate." 31 The moral justification of the law of negligence has support from higher authority. Lord Atkin said in Donohue v. Stevenson; ${ }^{32}$

The liability for negligence, whether you style it such or treat it as in other systems as a species of 'culpa', is no doubt based upon a general public sentiment of moral wrongdoing for which the offender must pay.

No doubt the origins of the law of negligence can be found in a concept of individualistic morality. ${ }^{33}$ But for a long time there have been elements in the law of negligence which make it utterly impossible to equate negligence with moral fault. Ever since Vaughan v. Menlove ${ }^{34}$ the test for negligence has been objective in the sense that the individual's own mental and emotional capacities are disregarded. $\mathrm{He}$ is held to the standard of the reasonable man. As Sir Nicholas Tindal pointed out in Vaughan v. Menlove, ${ }^{35}$

Instead, therefore, of saying that the liability for negligence should be co-extensive with the judgment of each individual, which would be as variable as the length of the foot of each individual, we ought rather to adhere to the rule which re quires in all cases a regard to caution such as a man of ordinary prudence would observe.

Thus, a man who does not have the capacity to meet a particular standard of conduct may be held negligent for not meeting it. This suggests to me that negligence is a sociological rather than an ethical concept. ${ }^{36}$ There may be on occasion an overlap between ethical blame and negligence but the two are not co-extensive.

Quite apart from the basis of the law of negligence, there are other features of it which make the allegation of individual moral fault far fetched. Vicarious liability is a prime example. And in many juris-

\footnotetext{
28 Laycraft, supra, n. 1 at 40 et seq. I might say in passing that 1 find it difficult to be enthusiastic about the no fault limited accident benefits plan which can be purchased voluntarily in most Canadian Provinces and which has been dubbed a "breakthrough" in Canadian automobile insurance by Professor A.M. Linden. See Insurance Amendment Act, 1966, Statutes of Ontario, $\mathrm{Ch}$. 71, S 11; Linden in Department of Transportation, Automobile Insurance and Compensation Study, Comparative Studies in Automobile Accident Compensation, "Automobile Insurance Breakthrough in Canada," 149(1970).

29 Compensation for Personal Injury in New Zealand, supra, n. 7 at para. 109.

30 Laycraft, supra, n.l at 37.

31 Id. at 38.

32 [1932] A.C. 562 at 580 .

33 James, An Evaluation of the Fault Concept, supra, n.4 at 395.

34 (1837) 3 Bing., N.C. 468, 4 Scot 244.

3s 3 Bing. 475 .

30 Montrose, Is Negligence an Ethical or a Sociological Concept? (1958) 21 Mod. L. Rev. 259.
} 
dictions, including Alberta, vicarious liability is imported by statute, ${ }^{37}$ so that in some circumstances the owner of the car will be held liable for the negligence of the driver even though the owner was not not in the car at the time of the accident.

Widespread insurance has diluted the fault concept still further, especially in the motor accident field. Insurance means that the person at fault does not pay for the consequences of his fault. Where compulsory insurance exists, negligence in terms of individual fault becomes even more of a fiction. In his advocacy of compulsory insurance, ${ }^{38} \mathrm{Mr}$. Laycraft is seeking to destroy altogether the very element in the negligence action which he finds most attractive. When compulsory insurance is imposed by legislation, that must reflect a judgment by society that the economic consequences of negligent conduct should be spread over the whole universe of potential defendants. In these circumstances it is the insurance company which becomes the real defendant. The company makes the decision whether to fight the claim in court. The company pays in the event of liability being established.

Personal blameworthiness, therefore, is not the rationale of the present law. Even if it were, in some theoretical sense, the presence of insurance precludes the responsibility from being driven home to those branded blameworthy.

The tort system does not compensate everyone who suffers personal injury by accident. An argument could be made that a new 20th century morality of community concern might demand that all victims should be compensated, whereas the 19th century individualistic morality upon which the tort system is based insisted that fault was a necessary prerequisite.

\section{The Uncompensated Victim}

Mr. Laycraft divides the uncompensated victims of accidents into four categories: gratuitous passenger, the victims of uninsured drivers, those injured in circumstances where there is no proveable fault, and those injured through their own negligence. $\mathrm{He}$ is willing to change present arrangements in Alberta to include compensation for the gratuitous passenger and those who are injured by uninsured drivers. Victims of accidents falling into the other two categories will just have to get on as best they can, as Mr. Laycraft does not propose to do anything for them. Yet in New Zealand where neither of the above limitations exist, there being a system of compulsory liability insurance and no guest statute, the fault system was still found to be unacceptable because too many victims were uncompensated.

Mr. Laycraft argues that proponents of compensation for those injured through their own negligence or where there is no proveable fault base their arguments on the allegation that the legal system cannot determine who was at fault. But the arguments in favour of similar treatment for all those who suffer injury in automobile accidents seem to me to be based upon much more profound grounds.

The argument is that when the accident problem is looked at in the wider context of the total environment, fault just does not seem

"7 Highway Traffic Act, S.A. 1967, c.30, s.210.

3s Laycraft, supra, n.1 at 42 et seq. 
important. First, accidents are statistically inevitable. The number of accidents on the road bears a relationship to the number of cars on the road. Accidents result from the community's collective choice in allowing people to drive motor cars on roads. Human nature being what it is and cars being what they are, it is impossible for this activity to be carried out without injury being sustained. Since society has not banished the motor car from the road or more vigorously limited its use, it must have made a decision in favour of accidents. ${ }^{39}$ Of course, in many of these accidents it is possible to determine fault, although the process is often unrealistic. The complicated environment in which we live is the overriding cause of the carnage of the roads. The split-second timing and all the other multitude of variables which go into driving on the highways make fault not so much impossible to determine as irrelevant. Where blameworthy conduct on the road precipitates an accident, the criminal law can bring to bear its sanctions against anti-social conduct. There seems very little reason for doing the job twice in some cases and in other cases determining civil fault in circumstances where there is no criminal fault and making compensation depend upon that determination.

Victims of motor accidents suffer losses. The common law allows a victim to shift the loss if he has been injured by another's fault. To ensure that those at fault can pay and those injured can collect, the risk of loss can be foreseen and the risk distributed by the mechanism of insurance, although who gets paid is still determined by the rules about loss shifting. For accident victims who cannot shift their loss the dislocating consequences of injury are not allayed. $\mathbf{A}$ man injured in a one car accident through his own negligence, even if that negligence is very slight, is likely to be in the position of losing substantial earnings which affects the very survival of himself and his family. For the uninsured driver of moderate means who negligently injures someone the consequences are similar. In both these classes of case the inattention of the driver may have been momentary; yet for a serious injury, the consequences of the accident are likely to be long term, not only to the driver himself, but also his dependants. To posit such long term consequences upon a momentary lapse seems disproportionately severe. To distinguish between accident victims on the basis of whether or not their injuries are the result of someone else's fault seems unreasonable. It is to presume a correlation between one ingredient among many which make up the circumstances of the accident and the long term consequences of the injuries sustained. Yet that relationship exists only after the event and when imputed by the law. The fault variable is not a sufficiently compelling part of the whole accident picture to be the controlling feature of it.

\section{Public Apathy toward Negligence}

Mr. Laycraft's suggestion that a no fault system of compensation would be distasteful rests on the morality argument discussed earlier and on the belief that the common law system is trenchantly supported by public opinion. ${ }^{40} \mathrm{I}$ regard this as doubtful. Professor Linden's study in Ontario points out that the majority of those who had had personal

:19 Calabresi. The Costs of Accidents, supra, n. 4, at 18.

"' Laycraft, supra, n. 1 at 39. 
dealings with the fault system did not favour it. A move away from the fault system may be, therefore, a "change which the people of our society want and not merely a change which the sociologist or moralist says they should want.41 Professor Linden also demonstrates that the more serious the injury the less favoured the fault system is as "a method of allocating the costs of their injuries by the individuals who are most likely to be in need of compensation." 42

Public opinion in the United States seems to be moving away from the fault system. In its recent study for the Department of Transportation the Survey Research Center at the University of Michigan found that toward the end of the interview after various features of auto insurance were discussed with the respondents more people expressed themselves in favour of a 'no fault' system. ${ }^{43}$

The more information people have about a no fault system, the more likely they are to approve of it. About three out of five of the Michigan sample said they were satisfied with the fault system. Yet, when given a description of a no fault system, about the same number said that they would favour it.44

The coming trend was summarized by the New Zealand Royal Commission as follows:

Nor is the philosophy behind the fault theory currently accepted by the man in the street. People have begun to recognize that the accidents regularly befalling large numbers of their fellow citizens are due not so much to human error as to the complicated and uneasy environment which everybody tolerates for its apparent advantages. The risks are the risks of social progress, and if there are instinctive feelings at work today in this general area they are not concerned with the greater or lesser faults of individuals, but with the wider responsibility of the whole community. 45

\section{Deterrence}

One of the least substantiated allegations made by Mr. Laycraft is that "the present torts system provides a deterrent to negligence by emphasizing individual responsibility." 46 Yet there would appear to be little deterrent value in the existing common law rules taking into account other influences on driving behaviour. The instinct of self preservation would appear to be one element which is likely to deter motor accidents. The criminal law has an elaborate system of sanctions such as fines, imprisonment and the cancellation of drivers' licenses which may have some deterrent effect in some circumstances. It is hard to see what an action for negligence adds by way of deterrence to the criminal law. The threat of a damages action can hardly prove a financial incentive if the defendant himself does not pay. In terms of deterring negligent conduct, tort law is marginal at best. What deterrent effect the common law system has in the automobile sphere would appear to be dependent upon differential insurance rates and personal liability for the uninsured portion of the damage caused.

11 Id. at 23 .

"2 Linden, The Report of the Osgoode Hall Study on Compensation for Victims of Automobile Accidents (1965), Attitudes, at 2.

43 Department of Transportation, Automobile Insurance and Compensation Study, Public Attitudes Toward Auto Insurance 74 et seq., (1970).

41 Id. at 79.

4 Compensation for Personal Injury in New Zealand, supra, n.7 at para. 89.

40 Laycraft, supra, n.1 at 40. 
The Michigan study for the Department of Transportation found that, The majority of people interviewed (58\%) felt that the presence of such [tort] liability makes no difference in the care with which people drive, with $17 \%$ averring that liability has some influence on driving behaviour and only $14 \%$ holding that liability in fact leads to careful driving. ${ }^{47}$

Regarding accidents causing personal injury, $68 \%$ of those interviewed thought that rules governing the imposition of liability made no difference to driving behaviour causing the accident.

The behaviour of the driver constitutes "only one of a multiplicity of causes of the accident." 48 There are three assumptions underlying the belief in the efficacy of deterrent measures. First, that the driver is capable of consistently safe behaviour. Second, that his lapses into unsafe behaviour are within his conscious control and are often deliberately committed because they may offer him some advantages. Third, that the threat of punishment will counterbalance the advantages he seeks to gain from unsafe behaviour. For a substantial number of accidents one or other of these assumptions is not valid.49

The deterrence concept most worthy of attention for reformers of accident law is Professor Calabresi's "general deterrence." This is a concept which depends on a sophisticated economic analysis to which it is difficult to do justice within a short compass. It is quite different from specific deterrence.

The crucial thing about the general deterrence approach to accidents is that it does not involve an a priori collective decision as to the correct number of accidents. General deterrence implies that accident costs would be treated as one of the many costs we face whenever we do anything. Since we cannot have every. thing we want, individually or as a society, whenever we choose one thing we give up others. General deterrence attempts to force individuals to consider accident costs in choosing among activities. ${ }^{50}$

The idea is that the cost of each activity ought to include the cost of accidents sustained in the course of that activity. The accident costs of the activity are then internalized, as the economist would put it. Contributions to a no fault system of compensation can be arranged to conform roughly to that principle by collecting the contributions to the fund as a charge on activities which cause accidents. A general deterrence approach makes it more attractive for an individual to engage in safer activities and it encourages those engaged in unsafe activities to make those activities safer in order to reduce the cost. There are a great many limitations to the practacability of

47 Department of Transportation, Automobile Insurance and Compensation Study. Public Attitudes Toward Auto Insurance, 67, table 7, (1970).

4* Department of Transportation, Automobile Insurance and Compensation Study, Causation, Culpability and Deterrence in Highway Crashes 117 (1970).

4 The Department of Transportation study on deterrence had some very interesting general comments: As behavioural scientists have developed a clearer understanding of human motivations and responses, their faith in efficacy of punishment in modifying the behaviour of the individual has diminished sharply. This has come about not so much from a recognition that punishment intended to deter often produces resentment and defiance instead, but rather from a recognition that punishing the individual will not inhibit antisocial behaviour if that behaviour is caused by personal or environmental factors that are beyond his control.

Along with this clearer understanding of the role of the environment has come the recognition that 'fault' or 'blame' is not a simple zero-sum matter but is highly complex and difficult to identify. Hence to punish the individual as being totally responsible for an antisocial action is not merely unfair but also ineffectual-since the individual is powerless to modify his behaviour to the extent that it is caused by factors in his environment...

The use of punishment as a deterrent has largely been replaced by educative and rehabilitative approaches to the individual and by a shift in focus from the individual to his environment. Although it has been more recent and less pronounced in traffic safety than in other areas that generate social problems, this change is gradually taking place ... Id. at 141.

so Calabresi, The Costs of Accidents, supro, n. 4 at 69. 
this theory. One basic problem is to decide which activity causes which cost. For example, when a pedestrian is injured in a motor accident is that a cost of driving or a cost of walking? Calabresi appreciates the limitations on the application of this concept but as one goal of accident law it is worth bearing in mind. As Calabresi points out, and this point is rather important to bear in mind later when the desirable shape of a no fault system is discussed:

There is... a tension ... between achieving the desired degree of primary accident cost reduction through general deterrence and minimizing the secondary costs of accidents through perfect loss spreading..$^{51}$

Calabresi's new book is essential reading for all those who wish to change the fault system, despite the fact that he offers no recipe for change.

\section{Damages}

Mr. Laycraft devotes little attention to the assessment of damages in the present system although it is a feature which presents grave problems for the retention of the common law.

According to the common law theory of assessing damages, the successful plaintiff is provided with full indemnity for all his losses. A large element of the assessment is pain and suffering. There is evidence in the United States that the total amount paid to settle a bodily injury claim under the tort liability system is on the average 2.4 times the amount of economic loss. ${ }^{53}$ Even accepting the proposition that pain and suffering has been too narrowly regarded in the past and that it is in reality an award to compensate the plaintiff for his loss of human dignity consequent upon injury, ${ }^{54}$ there seems to be an imbalance here. The priorities have got out of line. A bonanza for some and nothing for others is not the socially most beneficial use of the available funds. In addition, it seems to be the less severely injured who proportionately receive the largest awards for pain and suffering. ${ }^{55}$ The victims with the largest economic loss on the other hand, tend to be under paid. ${ }^{56}$ These anomalies apparently exist in Ontario, according to Professor Linden's study. ${ }^{57}$ There is no reason to assume, I suppose, that the position is much different in Alberta. The deficiencies seem to be the result not so much of the principles of the law of damages as the settlement practices of the insurance companies.

An even more alarming feature of the common law damages award is that it is virtually always made in the form of a lump sum. If the degree of permanent partial disability should increase after settlement there is no way in which this can be taken into account. There is also a substantial body of opinion which contends that periodic

si Id. at94.

sa Calabresi summarizes his genéral aim as follows:

What I have tried to demonstrate in this book is the more general proposition that a mixed system can be developed which does all the things we want in the way of accident cost reduction better than the fault system and does them consistently with our sense of justice. Id. at 312 .

ss American Insurance Association, Report of Special Committee to Study and Evaluate the Keeton-O'Connell Basic Protection Plan and Automobile Accident Reparations 16 (1968); Automobile Insurance: For Whose Benefit?, supra, n.6 at 26.

54 Blum and Kalven, Public Law Perspectives on a Private Law Problem, supra, n.4 at 35.

ss Automobile Accident Costs and Payments, supra, n. 4 at 197.

so Id. at 196-199 and 250-252.

37 Linden, supra, n. 42, Conclusions, at 4. 
payments are preferable to lump sum awards for social reasons. ${ }^{58} \mathrm{~A}$ system whereby future losses are compensated as the losses accrue seems to be sound, providing that there is certainty that payment will in fact be made. This system eliminates guess-work as to the claimant's chances of recovery, his life expectancy, and the cost of his medical treatment and rehabilitation. Periodic payments eliminate the possibility that the capital will be squandered. Mr. Laycraft argues that inflation can be quickly recognized in a system of court awards but is difficult to combat under a system of automatic payments. This is not true. It is simple to build into a compensation scheme automatic review of awards keyed to changes in the cost of living. The New Zealand Royal Commission recommended that in the legislation enacting its scheme there be provision for automatic adjustment of periodic payments at two yearly intervals to keep pace with changes in the cost of living. Adjustments were to be made up or down on the basis of consumers' price index for movements of $3 \%$ or more. ${ }^{59}$ Surely this is more rational than any hit or miss basis by which juries can predict future economic trends.

\section{Expense}

One of the most serious deficiencies of the common law system is the expense attached to it. The New Zealand Royal Commission said:

The ordinary observer would expect that payments of damages to successful plaintiffs would absorb a high percentage of the total sums needed by the common law system. We do not think that this is so. It is not possible on the evidence at present available to us to determine with precision the overall expense associated with the process, but we think it likely that more than 40 per cent of the amounts which are paid into the system are for various administrative and legal charges..$^{60}$

The British Columbia figure cited by Mr. Laycraft in which $\$ 1.60$ in premiums produces $\$ 1.00$ in payments to claimants is comparable to the New Zealand ratio.61 The situation in the United States is much worse, as the net amount of the premium dollar being paid to the victims is only 44 cents. ${ }^{62}$

Mr. Laycraft feels no sense of outrage at the Canadian figure. Quite to the contrary, he is prepared to justify the very high costs of the present tort system.

First, he argues that a comparison of the costs of a no fault system and those of present systems is impossible. Second, he argues that whatever the costs of respective systems, a no fault system does not differentiate between circumstances of claimants and it will accordingly "shock the sense of justice of all who observe it." 63 Both arguments seem to be doubtful. It simply is not true to say that no comparison between the costs of the common law system and the costs of a no fault system is available. In Canada where workmen's compensation is paid on a no fault basis and administered by public

\footnotetext{
st Compensation for Personal Injury in New Zealand, supra, n. 7 at para. 122; see also, Fleming, Damages: Capital or Rent?. (1969) 19 U.T.L.J. 295.

39 Compensation for Personal Injury in New Zealand, supra, n. 7 at para. 293.

w Compensation for Personal Injury in New Zealand, supra, n. 7 at para.111.

6. Laycraft, supra, n. I at 35.

62 R.E. Keeton in 1970 Supplement to 2nd Edition, Seavey, P. Keeton and R. E. Keeton, Law of Torts 259 (1970).

${ }^{63}$ Laycraft, supra, n.l at 36.
} 
corporations there is a very long and extensive record of administrative costs. The process of receiving and settling claims for injuries connected with work and those sustained in automobile accidents would appear to be very similar; the costs of administering the two processes then, would seem to be fairly comparable. The Ontario Workmens' Compensation Board's administrative expenses between 1960 and 1965 ran between 6.5 percent and 7.8 percent of the Board's total levies. ${ }^{64}$ And included in this figure are the costs of an elaborate rehabilitation and medical service. This low figure has been achieved in part by a centralized administration employing modern management techniques, especially computers. ${ }^{65}$ Of course efficiencies of this sort cannot be achieved easily, if at all, with a multitude of private insurance companies operating in the field, but there is no reason why a no fault system for automobile accidents must be tied into the existing insurance industry any more than the no fault workmen's compensation system in Canada is connected with private insurance. The recent Royal Commission in British Columbia erred in recommending that the insurance industry be allowed to continue in the automobile injuries reparations business. ${ }^{66}$ Harnessing the compensation dollar to its intended purpose, the compensating of those injured, should be a high priority. Every dollar spent on administration and legal expenses is a dollar not available to the injured victim. The waste ought to be eliminated.

The individual attention which common law principles of damages give to the claimant is a persistent theme in Mr. Laycraft's paper and in his view a major argument in favour of retaining the common law. The allegation here that a no fault system would shock the conscience rests on the assertion that a no fault system of compensation cannot do equity to individual claimants by responding to their individual circumstances. But a no fault system need not be so rigid. First of all, if compensation is tied to a percentage of the claimant's previous earned income it will vary with the individual's-economic circumstances and other needs in the same way that common law damages for economic loss do. Both Professor Ison and the New Zealand Plan propose this. ${ }^{67}$ There is no reason why there should be any upper limit to the wage levels compensated. Because of the low percentage of the population earning high incomes, at least in New Zealand, the extra cost of compensation is relatively small.68 Even though a schedule is a useful mechanism upon which to base assessments of permanent partial disability there is no reason why it must be rigidly applied. About 40 percent of the cases dealt with by the Ontario Workmen's Compensation Board are finalized on a schedule which is not even written into the legislation. ${ }^{69}$ Used as a general guide and not as an inflexible arbitrary measure, a properly constructed schedule can facilitate the settlement of claims. There must be no

\footnotetext{
4 Submission to Royal Commission on Workmen's Compensation in Ontario, Brief of Ontario Workmen's Compensation Board 15 (1966); Legislature of Ontario Official Report (daily ed.) December 17, 1969, at 9,784 .

ss Workmen's Compensation Board Sessions Book (Ontario), (April 9, 1969).

66 Province of British Columbia, 2 Report of the Royal Commission on Automobile Insurance 605 (1968).

67 The Forensic Lottery, supra, n.5 at 59; Compensation for Personal Injury in New Zealand, supra, n.7 at para. 292.

- Compensation for Personal Injury in New Zealand, supra, n. 7 at para. 439.

6o Workmen's Compensation Act, R.S.O. 1960, c.437, as amended.
} 
reluctance to depart from the schedule where circumstances demand -an obvious case is the concert pianist who loses a finger. There is nothing to prevent separate allowance being made in a schedule for pain and suffering and other common law heads of damages as well. Indeed, the whole panoply of common law damages as they now exist can be applied to a no fault system if the community desires it and will pay for it. Clearly the need for separate assessments in every individual case would raise the expense of administration, but if the courts were left out of it an expert tribunal could rapidly develop experience and precedent which would lead to greater expedition in dealing with claims. The demands of efficiency and individualization are not mutually incompatible. There is no reason at all why a no fault system must shock the conscience through arbitrary and unindividualized assessment of claims. To the extent that the British Columbia Royal Commission's proposals set an inflexible scale I agree with Mr. Laycraft's criticisms. ${ }^{70}$ But a curable defect in one no fault plan does not invalidate the concept. The difficulty the Wootton Commission in British Columbia faced was attempting to devise a system where benefits would be uniformly assessed by a polycentric insurance industry. That is very difficult unless the benefits are rigid, although it may be possible if an insurance industry were to accept outside control on the question of whom it paid and how much.

\section{Conclusion}

It must be acknowledged that there is a great deal about the workings of the automobile compensation system which is not known. There is a serious lack of empirical data on the operational consequences of the rules of tort law. How many people who are injured claim damages? How many succeed? How are the damages assessed? What do successful plaintiffs do with their damages? Other than the damages action, what other sources of compensation are there? What is the economic cost to society caused by accidents? What sort of medical attention do victims of accidents get? Who pays for it? What sort of insurance do people buy? Why? What do people think about the fault system? What do they think about their insurance companies? How can accidents be prevented? What deterrent effect resides in the present common law rules? What impact do the common law rules have on the rehabilitation of accident victims?

There are encouraging signs that the empirical work is being done. The pioneering work was done by Professor Conard and others at the University of Michigan. ${ }^{71}$ The United States Government is in the course of producing a study, twenty volumes of which have been published at the time or writing, which promises to be the best and most comprehensive attempt yet at providing answers to the questions. ${ }^{72}$ The Americans, in their inimitable way, tend to research

${ }^{70}$ Province of British Columbia,2 Report of the Royal Commission, supra, n. 66 at 606.

"Automobile Accident Costs and Payments, supra, n.4.

72 The following numbers have been published to date in the Department of Transportation, Automobile Insurance and Compensation Study: The Origin and Development of the Negligence Action; Public Attitudes Toward Auto Insurance; Automobile Accident Litigation; Economic Consequences of Automobile Accident Injuries (two volumes); Structural Trends and Conditions in the Automobile Insurance Industry Comparative Studies in Automobile Accident Compensation; Constitutional Problems in Automobile Accident Compensation Reform: Insurance Accessibility for the Hard-To-Place Driver; Mass Marketing of Property and Liability Insurance; Economic Regulation of Insurance in the United States; Causation, Culpability and Deterrence in Highway Crashes; Automobile Personal Injury Claims (two volumes); An Analysis of Complaints in Selected Automobile Insurance Markets; Insolvencies Among Automobile Insurers; $A$ Study of Assigned Risk Plans; Motor Vehicle Assigned Risk Plans; Rehabilitation of Auto Accident Victims; Price Variability in the Automobile Insurance Market (1970). 
problems to death, often, it seems, because they find it so difficult to get agreement on policy. While data is highly desirable and adds many insights, the broad principles of the tort system are sufficiently clear to enable an adequate appraisal of its worth to be made. One of the interesting aspects of the Woodhouse Report is the dearth of systematic empirical data to be found within its covers. Despite the relative ease of gathering information in a country as small as New Zealand the work had just never been done. The Commission had its staff search some of the court files for some of its information and the results are statistically dubious. ${ }^{73}$ But there was sufficient information available from a number of sources to see the broad outlines of the problem and the lack of detailed statistics in some areas was not seriously damaging because the Commission developed its arguments through the powerful exposition of principle.

\section{NEW PERSPECTIVES FOR ACCIDENT LAW}

Empirically obtained data is not in itself a sufficient basis upon which to overthrow the present system and build something else in its place. It is necessary to construct a conceptual framework for analysing and ordering the various goals of accident law. Professor Calabresi has been a pioneer in this field, ${ }^{74}$ although he has not proceeded without a stern challenge from Professors Blum and Kalven. ${ }^{75}$ A clarification of the goals of accident law and the analysis of the consequences of the various choices available is indispensable to soundly based social engineering in accident law. As soon as you begin to think of ways to reform the method of compensating victims of automobile accidents you are forced up against some hard decisions in the area of general welfare law. What sort of response do you want to make to a problem caused by human behaviour and resulting in human suffering? In the end you have to ask yourself what sort of society you want.

\section{The Victim of Automobile Accidents as a Special Class.}

The first question is, what is distinctive about an injury sustained in an automobile accident as compared with injuries resulting from other causes? A principled distinction is impossible. Therefore the victims of automobile accidents ought to be treated in the same way as victims of other accidents.

If the automobile reparation system is put on a no fault basis then the man I run over in my motor car will be compensated; if I run over the same man in my motorboat on the river he will need to prove negligence. What justification is there for the difference?

In terms of numbers, motor accident injuries no doubt represent a serious problem. However, injuries from motor vehicle accidents are probably not nearly as numerous as accidents connected with work. And injuries which are connected with neither work nor motor vehicles may be as numerous as work and road injuries combined,

73 Compensation for Personal Injury in New Zealand, supra, n.7 Appendix 6.

"Calabresi, The Costs of Accidents, supra, n. 4; and the following articles: Transaction Costs, Resource Allocation, and Liability Rules-A Comment, (1968) $11 \mathrm{~J}$. Law \& Econ. 67; Views and Overviews, [1967] U.Ill. L Forum 600; The Decision for Accidents: An Approach to the Non-Fault Allocation of Costs, (1968) 33 Law \& Contemp. Prob. 429; Some Thoughts on Risk Distribution in the Law of Torts, (1961) 70 Yale L.J. 499.

${ }_{75}$ Blum and Kalven, The Empty Cabinet of Dr. Calabresi: Auto Accidents and General Deterrence, (1967) 34 U. Chi. L. Rev. 239; Calabresi, Fault, Accidents, and the Wonderful World of Blum and Kalven, (1965) 75 Yale L.J.216. 
although the proportion of severe injuries will be less. One of the difficulties is that the comparative figures are not easy to obtain. But New Zealand government officials estimate the New Zealand figures for the year ended 31 March 1969 as follows:

$$
\begin{array}{lr}
\text { Work } & 80,000 \\
\text { Roads } & 20,000 \\
\text { Other } & 100,000 \\
\text { Total } & 200,000 \text { [which includes } 1,500 \text { fatalities] }{ }^{76}
\end{array}
$$

Of those injuries, it is estimated that 150,000 were sustained by those actively engaged in the work force.

Facing up to this situation the New Zealand Royal Commission formulated a new principle of accident law which converted the question into one of social insurance. The Commission formulated its first basic principle in terms of community responsibility for hardships accruing from injury. ${ }^{77}$

\section{Sickness and Disease}

The question must be faced from another level, too. If we decide to compensate all people who suffer bodily injury by accident, on what basis can we leave out those who get cancer or those who lose their jobs through economic recessions? As Professor Kalven has pointed out:

The point is that if one begins in another corner thinking about human misfor-

tunes and the use of social insurance to offset them, he may be moved to a large scale plan for handling of human misfortunes generally. ${ }^{8}$

The New Zealand Royal Commission admitted that under its approach there was logically no reason for excluding disease from its proposed arrangements. But it did advance some practical arguments for not including disease. The change recommended by the Commission was very bold in itself, the inclusion of disease would have made the projected changes massive. The Commission also thought that there was an urgent need to coordinate the unrelated systems of common law, workers' compensation and social security which characterised the New Zealand response to the injury problem. That task was sufficiently large without dealing with sickness and disease at the same time.

The Commission was concerned, too, with the absence of adequate statistical information from which to judge the magnitude of the disease problem and to enable calculations concerning the cost of including disease within its scheme to be made. ${ }^{79}$

76 White Paper, supra, n. 9 at 9. Professor Ison, Tort Liability and Social Insurance, supra, n. 5 at 615, citing from the Dominion Bureau of Statistics Causes of Death, Canada, (1966), comments:

Measured quantitatively, injuries and deaths resulting from motor vehicle accidents may be less than those resulting from accidents in the home, and are certainly much less than disabilities and deaths resulting from disease.

77 The Commission enunciated its concept of community responsibility as follows:

$\ldots$ in the national interest, and as a matter of national obligation, the community must protect all citizens (including the self-employed) and the housewives who sustain them from the burden of sudden individual losses when their ability to contribute to the general welfare by their work has been interrupted by physical incapacity.

... This first principle is fundamental. It rests on a double argument. Just as a modern society benefits from the productive work of its citizens, so should society accept the responsibility for those willing to work but prevented from doing so by physical incapacity. And, since we all persist in following community activities, which year by year exact a predictable and inevitable price in bodily injury 80 should we all share in sustaining those who become the random but statistically necessary victims. The inherent cost of these community purposes should be borne on a basis of equity by the community. Compensation for Per. sonal Injury in New Zealand, supra, n. 7 at paras. 55-56.

7s Kalven, A Schema of Alternatives to the Present Auto Accident Tort System, supra, n. 4 at 39.

70 Compensation for Personal Injury in New Zealand, supra, n. 7 at para. 17. 
A possible justification for treating traumatic injury as distinct from sickness and disease is that the law has long made a distinction between the two, although admittedly only in respect of injury caused by negligent conduct. There are difficult assessments to be made in the compensating of traumatic injuries and the process bears little relation to the manner in which welfare benefits are administered. Unless compensation for traumatic injury is paid on a flat rate basis, therefore, a separate mechanism for assessing degrees of disability would seem to be necessary and desirable. There are occasions upon which such assessments would be necessary for sickness and disease but the considerations would appear to be rather different. For example, an old age pension might be understood as compensation for general physical deterioration. However, such pensions are never assessed on that basis and it would be difficult to devise a method of doing so, or a rationale for doing it.

The other feature of a personal injury scheme which might dis tinguish it from a scheme dealing with disease as well is the need to see that the costs of accidents are not externalized, thereby preserving in Professor Calabresi's phrase, the possibilities of general deterrence. This would seem to entail drawing contributions for the compensation fund from industrial concerns, motorists and perhaps other agencies causing accidents.

All this is not to say that the way in which the personal injury problem is handled should be ignored when deciding what to do about sickness and disease. A substantial equity between the way in which the two problems are handled in the social system must be reached. And there are serious problems which must have developed in many countries as well as in New Zealand concerning overlapping benefits ${ }^{80}$-welfare benefits being available for injury in respect of which common law and/or workmen's compensation remedies are also available. It is important to repeat that in New Zealand a new Royal Commission was set up to investigate the whole problem of welfare programmes and Social Security while parliament was still considering the recommendations of the Royal Commission on Personal Injury. ${ }^{81}$ The new Commission has wide terms of reference and has been looking at the possibilities of bringing in an earnings related welfare scheme. ${ }^{82}$ There is a case for treating the compensation of traumatic injury separately, although not in isolation from the problems raised by sickness and disease. Now that the New Zealand government has decided the pattern of the new compensation plan, the new Royal Commission on Social Security will be able to fit its recommendations for compensating sickness and disease into that framework.

It is true that there are difficulties at the margin in delineating the border line between injury by accident and disease. ${ }^{83}$ But these difficulties exist now, both for the common law and workmen's compensation and if the general welfare system provides adequate assistance

\footnotetext{
so White Paper, supra, n. 9 at 132.

81 The Christchurch Press, November 25, 1969, back page.

2 Combined State Services Organizations, Submission to Royal Commission on Social Security. See The New Zealand Herald, May 27, 1970, at 33, col. 3. as New Zealand Orthopaedic Surgeons, Submissions to Parliamentary Select Committee on Personal Injury, at
35 (1970).
} 
to the victims of disease the difficulties of delineation ought not to bring unjust results. The New Zealand Royal Commission suggested using the International Classification of Diseases to make the demarcation simpler. ${ }^{84}$

\section{Prevention of Accidents}

There is an additional reason for dealing with the consequences of traumatic injury separately from general welfare schemes. Personal injury has different causes from those of disease. One of the strategies for dealing with all injury comprehensively and compensating it through a single agency is the opportunity that such an arrangement gives for gathering information and doing fundamental research on the underlying causes of accident. The prevention of accidents and the promotion of safety must be a high priority in any compensation scheme. The tort system offers no impetus at all in this area. A central authority administrating a comprehensive compensation scheme would have access to unique data on accidental injury, data covering all accidents not just some. Alcohol, drugs, poisonous gas, emotion, frustration, malice and suicidal tendency are only some of the factors which have been identified as causes of accidents. ${ }^{85}$ The opportunities for discovering fresh information on the causes of accidents and making new correlations concerning the various inputs would seem to be substantial. No such new opportunity is offered by a compensation scheme which deals with sickness and disease. Hospital admissions statistics and various other sources provide much data now. The medical researchers have not cried out for more data on disease in the same way as accident researchers. The study for the United States Department of Transportation concluded when surveying the automobile accident scene:

Fundamental to every facet of every traffic problem-at both the macro and micro levels -is the inadequacy of current reporting and hence the cumulative inadequacies of official data. The unreliability of the data makes virtually impossible the systematic evaluation of any counter measures without mounting an independent research effort aimed specifically at evaluation. ${ }^{86}$

If a central organization processed all accident claims and the victim had nothing to lose economically in making a full disclosure of all facts within his possession, new and comprehensive data would become available. This would offer a tremendous opportunity for carrying on research into accident prevention on a continuing basis. Of course, the problem mentioned in the Department of Transportation study exists for work accidents and it is even worse in respect of "other" accidents, about which we know very little. The development of safety education programmes is just one hopeful sign on the accident prevention horizon but adequate data is a prerequisite for progress in that area. If the personal injury problem is welded to a general welfare scheme there is a good chance that the safety and accident prevention aspects of such a program will become submerged.

\section{Rehabilitation}

Another basic aim of any comprehensive scheme for the compensa-

s4 White Paper, supra, n. 9 at 96.

as Id. at $98, \mathrm{n} .3$.

se Department of Transportation, Automobile Insurance Compensation Study, Causation, Culpability and De. terrence in Highway Crashes, 210-11 (1970). 
tion of personal injury must be the rehabilitation of injured people. By rehabilitation is meant the restoration of the handicapped to the fullest physical, mental, social, vocational and economic usefulness of which they are capable. Rehabilitation calls for a multi-disciplinary approach-not only are medical specialists required but also physiotherapists, occupational therapists, psychologists, specialists in vocational guidance and social workers. ${ }^{87}$

The manner in which compensation is paid can have an important effect upon the rehabilitation of an accident victim. The individual must feel secure about his personal circumstances and his ability to provide for any dependants. The accident neurosis cases with which personal injury lawyers are so familiar would be reduced markedly under a no fault system. The mechanism for assessing compensation should be made to assist in the achievement of rehabilitation rather than the reverse.

The New Zealand Royal Commission made rehabilitation a lynch pin of its arrangements saying that "the scheme must be deliberately organized to urge for the physical and vocational recovery of those citizens while at the same time providing a real measure of money compensation for their losses." 88

Effective rehabilitation is the best way to reduce the costs of accidents not only to the victims and their families but also to society as a whole.

\section{Workmen's Compensation Analogy}

It is hard for someone outside Canada to understand why the Canadians have devoted so little attention to one of the most persuasive models for reform right in their own back yard. The Canadian method of administering workmen's compensation fathered by Sir William Meredith in Ontario and brought into being in 1915 has been much admired overseas. It made plain very early the social insurance character of workmen's compensation. ${ }^{89}$ The former Chief Justice of Ontario Mr. J. C. McRuer has recently written an essay suggesting that the problem of compensating injuries resulting from car accidents "is capable of being solved on the same principles as the problem of compensating for injuries sustained in the industrial accidents" in Canada. ${ }^{90}$ One might suggest the same logic holds true for the victims of all accidents.

The British Columbia Royal Commission was more than a little cavalier in its treatment of the workmen's compensation model in its consideration of automobile injuries.91 Professor Ison points out that the British Columbia Commission made no attempt to show why conditions in British Columbia are different now from what they were in 1916 when workmen's compensation was first introduced on a government-administered basis. Neither does the British Columbia Royal Commission make any effort to review the arguments in favour of government administration.92

37 Cheit, Injury and Recovery in the Course of Employment (1961).

so Compensation for Personal Injury in New Zealand, supra, n. 7 at para. 55.

st Friedmann, Tort and Insurance in Law and a Changing Society 132-133 (1959).

20 McRuer, The Motor Car and the Law, in Linden (ed.). Studies in Canadian Tort Law, 303 at 318 (1968).

"I Ison, (1969) 47 Can. Bar Rev. 304 at 308.

92 Id. at 309 . 
The New Zealand Royal Commission, on the other hand, travelled to Canada and found in the Canadian workmen's compensation model a source of great inspiration. ${ }^{93}$ One of the features which made the greatest impact was the very low cost of administration of workmen's compensation in Canada ${ }^{94}$ compared to the workers' compensation in New Zealand which is administered by the insurance com. panies where the cost of administration is about $30 \%$ of the premium income. The emphasis on rehabilitation, proper medical services, and accident prevention are also characteristics of the Ontario system which impressed the New Zealand Royal Commissioners. ${ }^{95}$

Having made such a successful effort to deal with the problems arising in one sector of the personal injury problem, it is surprising that the same solution for dealing with other sectors has not commended itself to the Canadians. As Professor Kalven has pointed out the existence of the common law system and workmen's compensation has meant "that we have had a divided inheritance for at least fifty years." 96

The concern in the United States with motor accidents to the exclusion of everything else has been one of the more depressing features of the recent interest in compensation plans. There has been one recent American attempt to revive the workmen's compensation analogy-an article by Professor Henderson in the Texas Law Review. ${ }^{97} \mathrm{He}$ suggests that the workmen's compensation system be extended to non-occupational injuries. Professor Henderson reviews the other means through which individuals who are injured or ill may receive benefits, such as social security, welfare, private insurance and so on. He concludes that "the workmen's compensation system presently provides the greatest potential for private enterprise to respond to the growing demands of society for greater economic security and medical care in regard to disabling injuries and sickness." $98 \mathrm{He}$ proposes that the scheme be national and provide for wage loss reimbursement, and medical and vocational rehabilitation services for employees with an optional coverage for dependants. ${ }^{99}$ The programme would be financed jointly by employer and employee. Henderson envisages that his plan would be transitional and that some plan should eventually be devised to cover everyone in the society. Henderson prefers the workmen's compensation route to Social Security because the former is a private enterprise solution. Since workmen's compensation in the United States is run by private insurance companies he argues that the structure can be employed to demonstrate how social insurance can meet the problems of injury and sickness and at the same time "respond in a way compatible with the private enterprise economic system in the United States."100

2. Compensation for Personal Injury in New Zealand, supra, n. 7 paras. 131-133 and 208.

24 Id. at paras. 213-215 and 307 .

*. Id. at paras. 380-384, 430 and 310.

- Kalven, A Schema of Alternatives to the Present Auto Accident Tort System, supra, n. 4 at 36. Professor Kalven remarks. id.:

One might have thought that modern proponents of compensation plans would have sought to take advantage of this schizophrenic arrangement and would have argued that the common law system was fatally compromised by the adoption of workmen's compensation.

97 Henderson. Should Workmen's Compensation Be Extended to Non-occupational Injuries? (1969) 48 Tex. L. Rev. 117.

2s Id. at 148 .

99 Id. at 152 .

100 Id. at 157. 
I do not find this part of the analysis convincing. Private enterprise can only be considered if it can deliver comparable benefits at a comparable cost. A comparison between administrative expenses of workmen's compensation in Canada and in the United States would suggest that the private enterprise approach is too costly. Political ideology ought to give way to hard facts.

What emerges very plainly is that the existence of workmen's compensation in Canada with its low administrative costs resulting from centralized control is an admirable vehicle for dealing with other injury problems, yet there seems to have been little thought, apart from Justice McRuer's article, of extending it. One explanation for this may lie in the political power of the insurance companies.101

\section{THE NEW ZEALAND PLAN AND THE POLITICAL PROCESS}

It is one thing to decide what sort of compensation plan is needed. It is quite another to ensure its implementation. Now that the fundamental decisions have been taken in New Zealand it is worthwhile tracing the difficult progress of the Royal Commission's grand design through the political system. No attempt is made here to relate the New Zealand experience to any general model and produce a theory concerning the politics of compensation plans.

The overseas reader looking at accounts of developments on the compensation front in New Zealand ought not to forget the particular nature of New Zealand's political culture. Of the nearly 3 million inhabitants over half live in urban areas. Few societies exhibit such strong egalitarian traits. There is a good deal of income redistribution through a combination of heavy taxation and extensive social welfare programmes. As one New Zealand historian pointed out "the electorate has never been afraid of the state, and on the whole the state has served most of the people well."102 A tradition of strong and active central government, a unicameral legislature, strict party discipline all unmistakably dominated by Cabinet at once makes New Zealand politics simpler yet more delicate and responsive than in many other places. The structure of government is very much a stripped version of the Westminster model. But the way in which the political processes work is rather more involved. The major actors on the New Zealand political scene frequently have intimate almost collegiate relationships with one another-the system is close and personal. On the surface, at any rate, the system does not operate on the conflict model-it eschews public controversy. But this impression of serenity is misleading. The important decisions are fought about, although the struggle is behind closed doors, in caucus and in Cabinet and the Public Service. The mass media, on the whole, do not do an adequate job of sifting out what inputs go into these secret processes of policy formulation. To get change it is necessary to work gradually through the various interlocking components of the system. The Woodhouse Report began as an idea in the mind of a Minister of Labour perhaps stimulated by the Solicitor-General, now Chief Justice of New Zealand. The Minister secured Cabinet agreement to

sot This may account for the failure of the Wootton Commission to take account of the workmen's compensation model, and the failure of the Provincial Government of British Columbia to adopt the Commission's proposals. It is also remarkable to the outsider that the Saskatchewan model for automobile accidents in instances where negligence cannot be proved, which was introduced in 1946, has not been followed in any other Canadian Province. 
the appointment of the Royal Commission, which came down with recommendations even more radical that the Minister expected. The scheme was investigated by the policy making elements of the public service and funneled into the parliamentary system via Government caucus. Finding no substantial support, an effort was made to consolidate rather than go forward at that time, simultaneously ensuring that the Report could not become a serious issue in the General election of 1969. This was achieved by the strategem of a White Paper.

The Parliamentary Select Committee gave the politicians their first serious opportunity to come to grips with the issues at the same time releasing the tension of opponents of the scheme by letting them attack the Report and make alternative suggestions. Now the "Report on Reports" produced by the Parliamentary Select Committee on Personal Injury has been published and Cabinet has made a decision. It is inevitable that major changes will be made. Yet through all this the proposals have never caught the popular imagination, mainly because of their complexity and the inadequate way in which existing arrangements are understood by the community at large. Neither has there been any serious underlying catalyst for change, such as very high rates for automobile insurance, which seems to have been a considerable stimulus for compensation plans in the United States.

The point about the New Zealand experience which may distinguish it from other countries is that the electorate accepts the proposition that it is the duty of the Government to see that everybody has a job and a decent standard of living. ${ }^{102}$ Yet the difficulties which have become evident on the road to implementation of the Commission's proposals demonstrate just how strong and how strategically placed are the forces which are opposed to the recommended changes. This suggests to me that in harsher political climates reform of the New Zealand type may be altogether impossible. ${ }^{104}$

\section{Committee on Absolute Liability}

The story begins in 1962 . In that year a committee was set up by the government under chairmanship of the Solicitor-General, now the Chief Justice of New Zealand, Sir Richard Wild, to report on the desirability of introducing some form of absolute liability for death and injury arising out of the use of motor vehicles. The majority of the committee, which included representatives of insurance industry, trade unions, motoring interests and the legal profession admitted:

There is a case for an accident insurance scheme which would cover all persons who are injured in any way without negligence on their part, provided the community can afford to bear the cost on an equitable basis. ${ }^{105}$

\footnotetext{
102 Sinclair, A History of New Zealand 173 (1959).

103 Victoria University of Wellington, School of Political Science and Public Administration, Notes on New Zealand Government and Politics 21 (1969).

104 The British Columbia Royal Commission dismissed the New Zealand Royal Commission's approach very brusquely. In discussing whether its compensation plan ought to be administered publicly or privately the Brtitish Columbia Commissioners opined that the New Zealand Commission had a "strong bias against in. surance companies." Rather than evaluate the New Zealand approach, the British Columbians observed that, "In considering the New Zealand approach... one should not lose sight of the political theories and ideology prevailing there." 2 Report of the Royal Commission on Automobile Insurance, supra, $\mathrm{n} .66$ at 722. This seems short sighted. Dogmatisms of either the right or the left will not help in arriving at a solution to the accident problem. Does the fact that British Columbia banished private enterprise from work. men's compensation long ago, while New Zealand still retains it, say anything about the respective political theories in the two places?

10s Report of the Committee on Absolute Liability, at para. 40, (1963).
} 
The majority recommended, however, that "it would be unwise to make fundamental changes in our present system until definite recommendations can be made that such a change will bring improvements. ${ }^{106}$ The chairman, in a vigorous dissent argued that steps ought to be taken immediately. ${ }^{107} \mathrm{Mr}$. Wild later delivered an influential public lecture entitled "Social Progress and the Legal Process" which expanded his view and argued for an abolition of the common law system for compensating industrial accidents. ${ }^{108}$

\section{Royal Commission Established}

In 1966 the Government, on the recommendation of the Minister of Labour, the Hon. T. P. Shand, set up a Royal Commission to inquire and report upon workers' compensation which had been the subject of intermittent criticism through the years, largely due to the paucity of its benefits. Mr. Shand, an unusually frank and forceful man as New Zealand's politicians go, had said in Parliament as early as 1964 that he favoured the abolition of the common law for work connected accidents. ${ }^{109}$

The three members of the Royal Commission were Mr. Justice A. O. Woodhouse, a judge of the Supreme Court of New Zealand, Mr. H. L. Bockett, a retired Secretary of Labour who had publicly favoured reform of the Workers' Compensation Act which the Labour Department plays a part in administering, ${ }^{110}$ and Mr. G. A. Parsons, a prominent public accountant.

Trade union representatives in submissions to the Commission challenged Mr. Bockett's right to sit on the Commission because he had previously expressed "firm and positive opinions about specific points the Commission would be considering." 111 The Commission heard submissions from more than 70 organizations and individuals and travelled extensively overseas observing compensation schemes in operation and interviewing officials, compensation experts, and academics. ${ }^{112}$

The terms of reference of the Commission directed it to inquire into "the law relating to compensation and claims for damages and incapacity or death arising out of accidents (including diseases) suffered by persons in employment...."113 When the Commission reported in December of 1967 it was found that its recommendations dealt with all phases of personal injury and went far beyond injury suffered by persons in employment. There were suggestions that the Commission had exceeded its terms of reference, although that is arguable even on the face of the warrant. ${ }^{114}$ The Commission pointed out that it had found it "essential to examine the social implications of all the hazards which faced the work force, whether at work or during the remaining hours of the day." 115 It could find no justification for dis-

106 Id.

107 Id. at paras. 1, 2, 3 of the independent views of $\mathrm{Mr}$. Wild.

109 H. R. C. Wild, Q.C., Social Progress and Legal Process, (1965) 27 New Zealand Journal Public Administration 1.

108 The Christchurch Star, Editorial, September 25, 1964.

110 The New Zealand Herald, Editorial, August 26, 1964.

11: The Evening Post, September 29, 1966; The Christchurch Press, November 16, 1966.

112 Compensation for Personal Injury in New Zealand, supra, n. 7 at 194.

113 Id. at $11 \cdot 13$.

114 The final clause in the warrant was as follows, "Any associated matters that the Commission may deem to be relevant to the objects of the Inquiry." Id. at 12 .

is Id. at para. 34. 
criminating between accidents on the basis of their cause and accordingly recommended a comprehensive scheme to deal with all accidents.

Affected interests loudly proclaimed that they had not had an opportunity to be heard on the wider questions dealt with by the Commission. ${ }^{116}$

\section{Recommendations of the Royal Commission}

The Royal Commission found that the tripartite arrangements for compensation of injury in New Zealand were inadequate and anomalous. The Commission proposed a unified and comprehensive scheme of accident prevention, rehabilitation and compensation. Compensation was to be paid for all injuries irrespective of fault and regardless of cause. The common law action for personal injury was to be entirely abolished and the Workers' Compensation Act 1956 repealed. All persons injured at work, on the road, at home or in any way whatever, short of intentionally self-inflicted injury, were to be compensated. Benefits were to be paid in the event of death. The benefits were to be assessed on the basis of $80 \%$ of lost taxpaid earnings with a minimum and maximum. The maximum was set at $\$($ N.Z.)120 per week, a figure which would include $80 \%$ of the weekly earnings of nearly all the working population in New Zealand. Benefits were to be payable for life where necessary. Payments were recommended to be periodic rather than lump sum, except in instances of minor permanent partial liability. For those with no earnings or low earnings the Commission recommended that the lower limit of compensation be fixed in accordance with the existing social security sickness benefit for a single person. Assessments of permanent partial disability were to be made on the basis of a schedule, but the schedule was to be used as a guide only and not as an inflexible rule.

The Commission found that the present arrangements compensated short term injury rather more generously than they did long term injuries. Partly to redress the balance and partly to save money the Commission recommended that compensation not exceed $\$(N . Z)$. per week for the first four weeks of incapacity. After four weeks the limit would be removed and the injured person would receive the full $80 \%$ of his lost tax paid earnings if he were not already doing so. When a person was incapacitated for a period longer than 8 weeks compensation would be reassessed at the full rate of $80 \%$ for the whole period of incapacity including the first four weeks.

The Commission decided that no compensation would be paid to young people until they reached the age of 18 or unless they were, prior to that age, engaged in full-time employment and were receiving a wage of $\$(N . Z$.) 15 per week or more. From the date of the qualifying age compensation would be paid for past injury. No upper age limit was recommended. The Commission was of the view that both the elderly and the young must be included on a basis which recognizes their past or potential contribution to the productive effort of the nation.

The Commission proposed that its recommendations be financed essentially by taking advantage of the funds that are at present ex-

116 Insurance Council of New Zealand, Non-tariff Insurance Association of New Zealand, Personal Injury in New Zealand: An Initial Commentary on the Report of the Royal Commssion of Inquiry, para. 2 (1968). 
pended on compensation arrangements. It proposed, therefore, to collect from insured employers the same amount which is collected at present in the form of premiums. The funds collected from owners of motor vehicles for compulsory liability insurance would also be paid into the fund. The medical costs which are at present met by the state under the New Zealand system of socialized medicine would continue to be picked up. The only new items were to be a levy of $\$(N . Z)$.1.50 per annum on each driver's license and a levy on the self-employed, an amount equal to $1 \%$ of net income subject to an annual minimum of $\$(N . Z$.)5 and a maximum of $\$(N . Z$.) 80 . This arrangement meant that some groups eligible for compensation, housewives for example, would be making no direct contribution to the fund.

Although under the proposed scheme a similar sum would be collected from employers as is collected under the present employers' liability insurance arrangements it would be assessed on a different basis. Premiums under the employers' liability provisions of the Workers' Compensation Act are classified in the terms of degree of risk in the industry. There are about 140 separate classifications. ${ }^{117}$ The Commission argued that this method was inadequate in that it failed to recognize that "all industrial activity is interdependent."118 In place of this system the Commission proposed a uniform levy of one percent based on salaries and wages. This was to be a uniform rate on gross earnings. The great political attraction in this mode of financing was that it called for no increase in the levels of general taxation. On the other hand, it opened the Commission to the charge that it was ignoring its own principle of community responsibility. It can be argued that the principle of community responsibility calls for imposition of the burden of the scheme on all potential accident victims as a class-the whole community. Payment for matters of community responsibility usually comes from general taxation. The Commission met this argument by pointing out that the costs of the existing insurance arrangements must be assumed to have been built into the costs of industry and transport. If the premium ceased, there would be an advantage to industry at the expense of the general taxpayer to the extent that the premium costs were built into the costs of industry and the price of the product of the industry reflected these costs. This meant that the costs of compulsory insurance were already being met by the whole community indirectly as consumers, so the Commission argued.

The Commission proposed a comprehensive compensation scheme for virtually all injuries at an overall price very similar to that of the existing fragmented and selective remedies. The Commission estimated that the total cost of its arrangements including both benefits and administration would amount to $\$(N . Z)$.38 million compared to the $\$(N . Z$.)36.6 million which were being expended on the existing arrangements at the time it reported.

The Royal Commission envisaged its scheme being "brought to life and set upon its course" by an independent Authority. The Authority

117 Employer's Liability Insurance Regs. 1968, S/R 1968/35 (N.Z.). All money references to the New Zealand dollar, SN.Z. 1 = \$U.S. 1.12 .

11. Compensation for Personal Injury in New Zealand; supra, n. 7 at para. 1314. 
"should operate within the general responsibility of the Minister of Social Security and be attached to his department for administrative purposes."119 The Authority was to consist of a Board of three commissioners appointed for terms of at least six years. The chairman was to be a barrister of seven years practical experience. The Commission borrowed heavily from the structure and processes of the Workmen's Compensation Board in Ontario in its recommendations concerning administration.

The claims for compensation would be dealt with in the following manner. An application would be made for compensation accompanied by a medical certificate. The circumstances of the injury would be investigated and a decision made as to whether to start paying compensation. If the claimant did not agree with the decision he could request that it be reviewed by a review committee. If he was still not satisfied he could appeal to an appeal tribunal consisting of three persons, including a doctor and a lawyer. Hearings could be held at which the claimant could be represented if he wished. If the claimant were still dissatisfied he could appeal to the members of the Authority itself. On points of law an appeal to the Supreme Court could be had. 120

\section{Reception of the Royal Commission's Report}

The Report was received by the public in New Zealand, at least initially, without a great deal of comment. The Report itself was published during the Christmas-New Year holiday period of 1967-68, which is the southern summer. Since the issues with which it dealt were so complex, the newspapers had difficulty in doing more than merely producing boiled down accounts of what the Commission had recommended. Interpretative writing has never been a strong point of New Zealand journalists and informed balanced assessments of the Commission's proposals were almost entirely lacking. The papers restricted themselves, in the main, to accounts of the recommendations and what people said about them. A year after the publication of the report a journalist wrote that the Commission's proposals were so revolutionary that the interested parties "had been stunned into silence."121

There was more than a suspicion that the National Government, which had established the Royal Commission, was embarrassed by its

119 Id. at para. 307 (c).

120 Id. at para. 308(c). It is rather surprising to find that serious attempts at commenting upon and eriticising the Woodhouse Report have been relatively few; the material published in New Zealand includes McLauchlan, Compensation for Personal Injury in New Zealand, (1968) 3 Recent Law 13; Royal Commission to Enquire into and Report upon Workers' Compensation, Canterbury Chamber of Commerce Economic Bulletin No. 529 (1969); University of Auckland District Council of New Zealand Federation of Labour, Notes for Seminar on The Royal Commission Report on Compensation for Personal Injury (1968); The Woodhouse Report-A Panel Discussion, [1969] N.Z.L.J. 297; Woodhouse Commission Report: A Symposium, (1969) 2 Otago L. Rev. 32; Szakats, Towards Universal Social Insurance, (1968) Comment 35; Anderson, The Woodhouse Report on Compensation for Personal Injury in New Zealand, (1969) 1 Auckland University L. Rev., No. 2 at 1. Material published outside New Zealand includes Matheson, Compensation for Personal Injury in New Zealand, (1969) 18 I.C.LQQ. 191; Szakats, Compensation for Personal Injury: Individual Liability or Collective Responsi. bility, (1968) 3 U. Tasmania L. Rev. 204; Mathieson, Report of Royal Commission for Personal Injury in New Zealand, (1968) 31 Mod. L. Rev. 544; Parker, Socialized Insurance for New Zealand? July 13, 1968, 228 Economist xvii; Note, Compensation for Personal Injuries, (1968) 42 A.L.J. 283; Atiyah, Accidents, Compensation and the Law 608 (1970). There have been only occasional references in the American literature; Gregory and Kalven, Cases and Materials on Torts, 909 (1969); Keeton, Compensation Systems-The Search for a Viable Alternative to Negligence Law, at 223, n. 5, 231, n. 12 (1970 Supplement to Seavey, Keetion and Keeton, Cases and Material on Torts); Keeton. Venturing To Do Justice 139 (1969); Henderson, Should Workmen's Compensation Be Extended to Non-Occupational Injuries?, (1969) 48 Tex. L. Rev. 117 at $141 \cdot 142$.

121 The Auckland Star, December 24, 1968; Ballantyne, The Injured-A Survey, Part I. 
recommendations. The National party believes in private enterprise and it is generally more sympathetic to farming and business interests than New Zealand's other major party, Labour. But the recommendations of the Commission did have one powerful friend in Cabinet, the Minister of Labour, The Hon. T. P. Shand. He had welcomed the Commission's report as "a bold, imaginative document."122

For some months after the publication of the report the Government did nothing. In the meantime, the opponents of the Commission's scheme were beginning to muster their forces. In April 1968 the Chairman of the Committee of the Insurance Industry on Workers' Compensation gave a speech at a seminar held in Auckland attacking the report, especially the aspects of it which recommended that the insurance industry be permitted to play no further part in personal injury compensation in New Zealand. The speech was also highly critical of the Commission's cost estimates and flatly denied that the scheme could be brought into existence within the figure quoted by the Commission. ${ }^{123}$

About the middle of 1968 a Caucus Committee of the Parliamentary National Party began to study the Commission's report. An Interdepartmental Committee of high ranking public servants, the Secretary of Labour, the Solicitor-General, the Chairman of the Social Security Commission and the Secretary to the Treasury also began to study the Report and produced a forty-page study with four appendices which was presented to the Caucus Committee at the end of 1968. The government statistician had prepared independent cost estimates of the Commission's proposal for this study, which broadly confirmed the Commission's estimates. ${ }^{124}$ The Caucus Committee asked for a supplementary report on certain points: the financing of the proposals, the relationship of the scheme to social security, and the possibility of introducing the scheme in phases. This was presented to the Caucus Committee in late March 1969. ${ }^{125}$ Neither of the Reports by the officials to the Caucus Committee ever became public. The attitude of the officials' committee report was quite favourable to the Commission's proposals. The committee agreed that the common law action for damages should be abolished. Naturally the primary focus of their concern was with the feasibility of the scheme from an administrative standpoint. The Social Security Department was particularly concerned with the impact the new scheme would have on benefits presently administered by that department. There was some underlying conflict among the officials as to the precise role of the Social Security Department.

The attitude of the Caucus Committee seems to have been divided. Both the Minister and the Caucus Committee recognized that interested groups would need to be given further opportunity to make

122 Id.

123 University of Auckland, Department of University Extension and Auckland District Council, New Zealand Federation of Labour, Notes for Seminar on the Royal Commission's Report on the Compensation for Personal Injury in New Zealand, (Address of K. R. Congreve, April 23, 1968).

124 White Paper, supra, n. 9 at 66.

125 Report of the Inter-Departmental Committee on the Report of the Royal Commission of Inquiry into Com pensation for Personal Injury in New Zealand (1968) [mimeo]; Supplementary Report of the Interdepart. mental Committee (1969) [mimeol. 
submissions to the government before any action was taken. ${ }^{126}$ The Committee had had considerable difficulty in coming to grips with the complicated and far reaching issues inherent in the Commission's Report. That was about the only point upon which the Committee could reach a conclusion.

\section{Preparation of Government White Paper}

The Cabinet decided that a White Paper "should be prepared setting out the form in which the scheme envisaged in the Woodhouse Report would operate, if adopted, together with the principal variants or alternatives which might be preferred. This paper, when completed, would be made available for public study and groups and institutions affected would be given an opportunity to make submissions on matters of particular concern." 127 The Minister of Labour in his announcement of this step admitted that "there is an understandable feeling of restiveness among people who might be seriously affected by the implementation of the proposals." He emphasized, however, "that the proposals have not and will not be shelved and forgotten."128

Just a few days previous to the Minister's announcement the Insurance Council of New Zealand and the Non-tariff Insurance Association had released a second commentary on the Royal Commission's proposals which was highly critical. This had been widely publicized in the press. ${ }^{129}$ An initial commentary also highly critical had been circulated privately in July 1968 and later more widely distributed. Indeed there began to be a good deal in the newspapers about the insurance industry's view of the Report's weaknesses. This apparently was the result of the insurance industry retaining a major advertising agency to handle the public relations campaign against the Report. ${ }^{130}$

Early in April 1969 the New Zealand Law Society held its centennial conference at which there was a panel discussion concerning the Royal Commission's recommendations. Two private practitioners engaged in personal injury litigation spoke in opposition of the report. ${ }^{131}$ In addition, there was a good deal of discussion from the floor. The comments at the conference indicated that the New Zealand legal profession was by no means solidly opposed to the Report or to the abolition of the negligence action.

The president of the Federation of Labour, Mr. T. E. Skinner, addressed the annual conference of the Federation of Labour in April 1969 on the subject of the Royal Commission's Report. ${ }^{132}$ He stated it as his general conclusion that."the report sets out a desirable proposal and one which could be accepted in its entirety, subject only to minor revisions...."133 Mr. Skinner was not happy about the new

125 The Committee was chaired by the Minister of Labour, The Hon. T. P. Shand, who appeared to be in favour of the Commission's proposals but was prepared to listen to reasoned argument about their weaknesses. At least one member of the Committee. Sir Leslie Munro, a back bencher and a former diplomat and lawyer was known to be doubtful about aspects of the Report and made his feelings known publicly. [1969] N.Z.
L.J. 297 at 307 .

127 Press Statement by the Minister of Labour, the Hon. T. P. Shand, at 3, April 9, 1969. [mimeo].

12s Id. at 1 .

129 The Evening Post, March 27, 1969 at 16, col. 1.

130 The Dominion-Sunday Times, March 2, 1969 at 3, col. 1.

เง1 [1969] N.Z.L.J. 297 et seq.

132 (1969) 2 Otago L. Rev. 59.

133 Id. at 61 . 
levy on motor drivers' licenses. More predictably, he was concerned to point out that the workers' rights to a common law action should not be taken away. He stated that some "compromise" could be devised to deal with this. It is clear that periodic payments as opposed to common law lump sum payments were a matter of concern for some union members. ${ }^{134}$ What enthusiasm the Federation had for the Report was to wane later.

During the time the White Paper was being drafted public debate on the Royal Commission's proposals almost ceased. There were questions in the House of Representatives as to when the White Paper would appear ${ }^{135}$ and there were occasional reports such as one in which a New South Wales Judge visiting New Zealand, Mr. Justice J. K. Manning, praised the report as giving "sensible, practicable, and reasonable answers to a problem which had been before society for many years." 136

\section{The Commission's Proposals and the General Election of 1969}

The White Paper was laid on the table of the House of Representatives on 23 October 1969. ${ }^{137}$ In his introduction the Minister of Labour was careful to point out that the paper was "a working paper, not a statement of government policy."138 Mr. Shand pointed out that the government had taken no decision "beyond affirming its belief that the Royal Commission's recommendations are deserving of intensive study and that the proposal will not be shelved."139

The day after the White Paper was tabled in the House of Representatives, the House agreed to set up a Special Select Parliamentary Committee on Compensation for Personal Injury. ${ }^{140}$ The Committee would give those groups who wished an opportunity to make submissions. The procedure adopted by the Government in setting up such a Committee was not altogether constitutionally orthodox and was questioned by the Labour Opposition. ${ }^{141}$ Parliament was about to expire and the triennial general election was to be held on 29 November 1969.

In the ensuing election campaign the Labour Party promised to take immediate steps to draft legislation implementing most of the recommendations of the Royal Commission. The Leader of the Opposition, Mr. N. E. Kirk, described the report as "humanitarian, imaginative and farsighted."142 The only reservations the Labour Party held were toward some aspects of financing the proposals and the abolition of all common law rights. ${ }^{143} \mathrm{Mr}$. Kirk accused the government of failing to act on the Report although he was careful to point out that the Labour Party would also give interested groups the proper opportunity "to have their arguments considered." 144

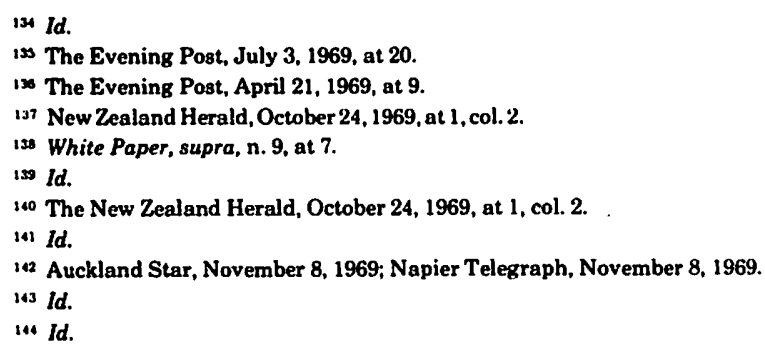


Despite allegations of procrastination, the National Government could say that it had prepared an intensive and extensive official study of the problems and put it before the public and was not going to act before interested groups had made their representations. In this way the government had protected its flank rather shrewdly and the Commission's proposals were not a major issue in the general election of 1969. The National Government won the General Election but lost ground to the Labour opposition. Shortly after the election, on December 12, the Minister of Labour the Hon. T. P. Shand died. He was widely acclaimed as an outstanding Minister of Labour. ${ }^{145} \mathrm{He}$ was third ranking member of the Cabinet and his passing may yet be shown to have been of crucial importance to the final shape of legislation which comes out of the debate in New Zealand. On the other hand, there is a body of opinion which holds that political acceptance of the Commission's principles has been easier since his death, as there was a feeling he was trying to ram the Report down his colleagues' throats.

\section{The Contents of the White Paper}

Few of the interested groups had a chance to digest the White Paper before the election. The White Paper including appendices was 173 pages in length. It complied with Tallyrand's admonition "above all no zeal." But it did establish a number of important facts which narrowed the scope of the debate on the Royal Commission's proposals and forced changes in tactics upon its opponents.

Virtually all of the Royal Commission's critics and some of its friends had impugned the cost estimates of the Royal Commission,146 despite the assistance the Commission had had from two mathematicians.

The White Paper contained an extensive section on costs, including a full re-estimate of the costs of the scheme. These cost estimates consisted of Government Statistician's estimates as given to the Interdepartmental Committee in December 1968 updated to March 1969. The validity of the estimates were also checked and the estimates were broken down into their component parts. An extensive appendix on costs was included explaining the methodology employed in arriving at the estimates and setting out the technical data upon which the computations had been based. The expense of possible variations to the Commission's scheme were also calculated. The estimates contained in the White Paper were that the total cost of the Commission's scheme would be $\$(N . Z$.) 43 million per annum with a margin of possible variation plus or minus $\$\left(N . Z\right.$.) 6 million. ${ }^{147}$ The updated estimate of the scheme's income through the sources proposed by the Commission was $\$(N . Z)$.46.1 million. This meant that the scheme was likely to balance financially. The White Paper presented the arguments for and against the present arrangements for compensation in New Zealand rather more dispassionately than the Royal Commission had done. It pointed out that the first decision for the Government to make was whether or not the Royal Commission's evaluation of these arrangements was

145 Nelson Evening Mail, Editorial, December 11, 1969.

146 [1969] N.Z.L.J. 297 et seq. It has been characteristic of the debate in New Zealand that individuals and sroups with no special expertise in statistics have repeatedly doubted the cost estimates for the scheme without disclosing a basis for doing 80 .

147 White Paper, supra, n. 9 at 64. 
broadly correct. ${ }^{148}$ The next decision for the Government was whether or not the Commission's principle of community responsibility ought to be accepted. 149

The paper discussed a number of possible variations to the Commission's proposals which could be considered. The possibility of including sickness and disease within the scheme was mentioned. The alternatives available in choosing some age limits for the payment of compensation were discussed, although it was pointed out that "all such proposals represent a derogation from the principle of comprehensive entitlement." 150 There was extensive discussion about the various levels of compensation which could be chosen. It was suggested that the limit on the amount of compensation for the first four weeks which had been suggested by the Commission could be eliminated. There was also a discussion about the possibility of including some allowance for pain and suffering and other heads of common law damages perhaps on the basis of a schedule. There was a lengthy discussion concerning the desirability of treating compensation under the Commission's proposal as taxable income. The Commission had rejected taxation of compensation although the discussion in the White Paper tended to favour it. The White Paper agreed with the Commission that periodic payments were preferable to lump sum payments although there was no extensive discussion on this question.

There had been some suggestions that due to the wide ranging nature of the Commission's proposals the recommendations could be introduced in steps. This possibility was discussed in the White Paper and it was concluded that phasing "presents difficulties of both practice and principle."151

In one respect the White Paper took serious issue with the Royal Commission's approach. It will be remembered that the Commission had proposed that its scheme be financed in part by a flat $1 \%$ levy on salaries, wages, and earned income. The White Paper discussed the possibilities of a graduated levy according to the occupational risk of accident in each industry. It was argued that such a system might be more efficient in deterring accidents than if the costs were spread through the community. The possibility of devising a similar graduated levy in respect of automobiles was also mentioned. The approach of the White Paper on these questions was taken up and approved by the Select Committee recommendations.

The problem concerning the new compensation Authority's role in the prevention of accidents and rehabilitation was dealt with. These sections of the White Paper proved extraordinarily difficult to draft due to the need to fit the new scheme into the pattern of existing arrangements in these fields. ${ }^{152}$ Some Government Departments had

\footnotetext{
148 Id. at 139.

169 The White Paper, id. at 45, observed:

Whether this premise is accepted or not is a question involving the relationship of the individual and society. If the premise is accepted some coordinated response must be made to the Commission's fundamental principle outside the framework of present arrangements. If the goals are agreed upon the debate can only be about the best methods of achieving the stated goals. Even if the premise of 'combate can only be about the best methods of achieving the stated goals. Exvidual nevertheless has such a stake in the safety, rehabilitation, and maintenance of the work force as to justify the introduction of a comprehensive compensation scheme on economic grounds.

tso Id. at 140.

151 Id. at 79.

132 Id. at 98-111.
} 
vested interests in some aspects of safety and rehabilitation which they were reluctant to give up.

Another matter of central concern to officials on the Interdepartmental Committee was the management of the scheme. ${ }^{153}$ A lengthy discussion of the administrative arrangements is contained in the White Paper. It is clear that this aspect of the matter is likely to cause some difficulty still in government administration in New Zealand. The administration of the Commission's scheme called for an organization to manage the funds, assess the claims, distribute the benefits, rehabilitate the injured, promote safety and do all these things efficiently and inexpensively. The Royal Commission had been implacably opposed to private enterprise administration of its scheme, reasoning that private enterprise was too expensive; that it played no part in obtaining the business since the scheme was to be compulsory; that the funds were public funds from which it was not appropriate for private companies to profit; that private enterprise could offer no central impetus in accident prevention and rehabilitation. ${ }^{154}$

The White Paper was less dogmatic on this matter, as, indeed, being published under the auspices of a National Government, it had to be:

Grounds of cost, rather than of principle, may indeed be the controlling factor in the choice between private enterprise and public authority. If private enterprise were able to devise a comparable system of comprehensive benefits to that proposed by the Commission which can be delivered at approximately the same administrative cost as the Commission's, such an alternative could be considered. ${ }^{155}$

The White Paper made a number of tentative suggestions as to how the insurance companies could be used in running the scheme. ${ }^{156}$ Among them was one which suggested that the insurance companies might be compensated "by way of set fees for work done."157 This brief remark was later developed by the Parliamentary Select Committee into the basis of its approach to the management of the scheme. The Committee's ideas will be reviewed later in this paper. The Royal Commission had recommended that the Social Security Department act as the main servicing agent to the Authority in the administration of the scheme. There was concern in various quarters that if the whole scheme was handed over to the Social Security Department in this manner that the administration might tend to be arbitrary and unfair. ${ }^{158}$ The experience of the Department was principally with flat rate benefits.

The White Paper also discussed the basic decision to be made as to what extent administration of the scheme should be decentralized. One of the most useful aids in administering a scheme of this sort is the computer, which in itself makes for a degree of centralization. The use of the insurance companies proposed by the Select Committee will necessarily involve a decentralized system of administration which may raise costs.

There was some material in the White Paper as to what extent

\footnotetext{
iss Id. at 112 et seq.

154 Compensation for Personal Injury in New Zealand, supra n. 7 at paras. 207.217.

135 White Paper, supra, n.9 at 114.

136 Id.

157 Id.
}

154 New Zealand Law Society. Submissions to the Parliamentary Select Committee on Personal Injury (1970). 
rights of appeal to the Supreme Court should be permitted in respect of claims made to the Compensation authority.

The discussion of miscellaneous problems included the automatic adjustment of periodic payments in compensation rates at yearly intervals; the compensation of New Zealanders injured overseas; the compensation of visitors to New Zealand who are injured; the exclusion from the scheme of injuries which were deliberately self-inflicted. On the last point the issue of whether persons injured during their indulgence in certain classes of anti-social behaviour, such as the commission of an indictable offence was argued. It was suggested that the criminal law could provide sanctions enough in the punishment of blameworthy conduct.

The problem of overlapping benefits between the compensation scheme and social security and war pensions was briefly discussed. There are likely to be very difficult administrative problems in the implementation of the scheme. And no attempt was made to resolve them. It was suggested that the new Royal Commission on Social Security would be able to deal with the problem when it determined the future shape of the Social Security System. ${ }^{159}$ This was a neat way of escaping a very intractable problem.

\section{Reaction to the White Paper}

In general, the White Paper sought to demonstrate the feasibility of the Commission's scheme from a neutral standpoint. The public reaction to the publication of the document indicated that it succeeded in its purpose. The Otago Daily Times pointed out in an editorial,

The report of the top officials on these schemes had one important . . . basic conclusion. It established that the Commission's proposals were not simply 'pie in the sky'. It also revealed that, as the Commission had forecast, the cost of the new scheme would not differ seriously from the cost of the present fragmented operations. And, reading between the lines, it suggested that the officials not only considered the scheme workable, but that they liked it. ${ }^{160}$

The Auckland Star commented concerning the White Paper,

It shows that the Report has stood up well to official scrutiny. Two years ago there was disbelief that the comprehensive system recommended could be provided without much increase in the cost of the present fragmented system. The cost and revenue estimates are confirmed. ${ }^{161}$

The editorial pointed out that New Zealand had known for two years that it could have a much better and more comprehensive system of personal injury compensation for very little greater cost than its present arrangements. The paper commented that what was still lacking "is any sign of political commitment to change." 162

The Christchurch Press said it would be helpful "on a matter of such prime social significance, if bipartisan agreement could be reached on general principles so as to avoid political controversy. The reference of the Woodhouse Report to a select committee of Parliament is therefore to be welcomed."163

\footnotetext{
159 White Paper, supra, n. 9 at 134.

160 Otago Daily Times, Editorial, October 23, 1969.

361 The Auckland Star, Editorial, October 24, 1969.

162 Id.

163 The Christchurch Press, Editorial, October 25, 1969.
} 


\section{The Timaru Herald commented,}

Real, hard discussion of the plan has been a long time in coming. It is to be hoped that the White Paper will spark a debate which will leave the general public much better informed on the issues and in a position to reach a decision. ${ }^{184}$

\section{Proceedings of the Parliamentary Select Committee}

The Parliamentary Select Committee consisting of six Government members and four Opposition members began hearing submissions in February 1970. Altogether forty-five organizations and individuals made submissions. These submissions were heard in public and were completed by the middle of June 1970. After that Government Departments gave their views to the committee in camera. ${ }^{165}$

Taken as a whole the submissions showed that hardly any organization or individual was content with the status quo in compensation arrangements. There were, however, widespread differences as to what were the appropriate means of remedying the situation.

\section{a. Insurance Industry Submissions}

The most important submissions came from the Insurance Industry Committee representing the Insurance Council of New Zealand and the Non-tariff Insurance Association of New Zealand. ${ }^{166}$ The submissions showed a marked change of attitude from earlier commentaries on the Royal Commission's Report made by the industry.

As the White Paper had pointed out the implementation of the Report would probably mean that insurance offices would lose premium income of approximately $\$(N . Z)$.30 million a year, a little less than half of their accident insurance business. This would be a loss of about $1 / 6$ of their total premium income. It was anticipated that such a change might force small companies out of business and cause some staff readjustments. More than sixty insurance companies do accident business in New Zealand.167 It was also suggested that the ability of some insurance companies to subscribe to government loans might be affected although this could be overcome by requiring the new Authority to invest substantial portions of its funds in government stock.

In the submissions to the Select Committee the insurance industry dropped most of the extreme and insupportable comments made in earlier commentaries of the Insurance Industry Council. Statements such as "these recommendations have no contact at all with the realities of New Zealand today; they are nothing more than wishful thinking"168 and that the report was "inherently unsound-unsound in fundamental principles, unsound in its financial assumptions, unsound in its administrative proposals" 169 or "the scheme cannot be regarded as anything other than suspect" were not repeated. ${ }^{170}$ Most important of all, the

164 The Timara Herald, Editorial, October 28, 1969.

185 The Auckland Star, June 22, 1970, at 8, col. 6.

160 The Insurance Industry Committe, representing the Insurance Council of New Zealand and the Non-Tariff Insurance Association of New Zealand. Submissions to the Parliamentary Select Committee on Compensation for Personal Injury (1970).

187 White Paper, supra, n. 9 at 41.

168 Insurance Council of New Zealand and the Non-tariff Insurance Association of New Zealand, Compensation for Personal Injury in New Zealand-An Initial Commentary on the Report of the Royal Commission of In. quiry 14 (1968).

169 Insurance Council of New Zealand and the Non-tariff Insurance Association of New Zealand, Compensation for Personal Injury in New Zealand-A Second Commentary 3 (1969).

170 Id, at 11. 
allegation that the Commission's costing was erroneous was dropped. The new strategy of the insurance industry was to make a take over bid for the right to run a scheme which, on the surface, looked somewhat similar to that recommended by the Royal Commission. The industry's position was that existing compensation arrangements could be "upgraded in a sufficiently flexible form to serve the nation for many years to come." The industry proposed that entitlement to compensation be automatic and no proof of negligence be required in respect of injuries sustained in the course of employment or injuries caused by road accidents. In respect of claims where there was more than $\$ 20,000$ economic loss and/or $\$ 5,000$ physical or intangible loss, the right to a common law action was to be preserved. But there would be no compensation for other accidents, except the existing common law remedy. Self-employed persons would not be covered by the scheme unless they volunteered to become insured under it. The coverage was to apply twenty-four hours a day to people of all ages. ${ }^{171}$

It was pointed out in other submissions to the Select Committee analysing the insurance industry's plan that the plan had serious weaknesses when viewed against that proposed by the Royal Commission. ${ }^{172}$ First of all the insurance industry's plan rejected the Commission's principle of community responsibility. It did not establish benefits on the basis of comprehensive entitlement. "Other" accidents were entirely excluded from the scheme. And as was noted earlier these are as numerous as work connected accidents and road accidents together. Neither did the Insurance Committee's proposal give any indication that there would be the "imagination, drive and leadership," in the fields of rehabilitation and accident prevention upon which the Commission's proposals had placed weight.

The level of benefits even in respect of the accidents covered by the Committee's proposals were substantially less than those offered by the Royal Commission's Report. It will be recalled that the Woodhouse proposals paid up to $\$(N . Z)$.120 per week. In addition, the Committee's proposal suffered from the same deficiency as the New Zealand workers' compensation scheme-over a period of years the seriously injured person would run through the total amount of $\$(N . Z) 20,$.000 allocated to him and would become a charge on the state.

There is a trenchant defence of the common law action for damages in the insurance industry's submissions. ${ }^{173}$ One might have assumed that were the common law defensible as an instrument for compensation in the personal injury field it would be defensible on a total rather than a truncated basis. It can be argued, too, that if a two track sys-

171 Insurance Industry Submissions, supra, n. 166. Compensation would be paid on the basis of eighty-five percent of lost gross wages up to a maximum of $\$ 70$ per week. Total compensation payable to any one person in respect of any one accident would be limited to $\$ 20,000$. Payments were to be periodic but all benefits could be commuted to a lump sum at any time during entitlement at the option of the beneficiary. Weekly compensation would be taxable in the recipient's hands. If paid in a lump sum the compensation would be tax free. In respect to claims where there was more than $\$ 20,000$ economic loss and/or $\$ 5,000$ physical and intangible loss the common law remedy would be preserved. A complicated system of death benefito was proposed which varied according to whether or not the person killed left dependento. Disputes would be settled by resort to the ordinary courts. It was recommended that either party should have the right to move the court for a ruling in some expeditious way. Jury trial would apparently still be available for claims above the level of benefits offered in the no fault scheme. It was estimated that the cost of these proposals would be $\$(N . Z)$.22.8 million plus or minus $\$(N . Z)$.3 million. This figure, however, excluded the costs of administration, and costs of the common law system for the accidents in respect of which that remedy was retained.

172 Palmer, Submissions to the Parliamentary Select Committee on Compensation for Personal Injury 9 (1970).

173 Insurance Industry Submissions, supra, n. 166 at 8. 
tem involving both fault and no fault compensation is proposed it is better to give all victims the right to a common law action while providing minimum benefits in the event of fault not being proved. This, of course, is the Saskatchewan approach. ${ }^{174}$

Despite the weaknesses of the Insurance Industry's proposals compared with those of the Royal Commission, the proposals do seem as liberal as any which have been made by an insurance industry anywhere. They must be taken as an indication that the industry did not feel that it could maintain the status quo much longer without responding to the pressures for change.

\section{b. Submissions from Organizations Representing Workers}

Taken as a whole one salient point emerged from the submissions made by trade union leaders and their advisers to the Select Committee. ${ }^{175}$ While there were kind remarks about the humanitarian cast of the Royal Commission's Report, and the desirability of a system of absolute liability, there was concern with the specific proposals concerning amounts of compensation. The Federation of Labour opposed the enactment of the Royal Commission Report in its present form because of "the inadequacies which would leave some members of the community worse off than they are under existing arrangements."176 This inadequacy in the eyes of Labour leaders appeared to emanate from two sources. The first was the non-application of the $80 \%$ of previous tax paid earnings standard for compensation during the first four weeks of incapacity. The second reason for disquiet seemed to be the fact that union members would no longer be able to pursue, in Professor Mathieson's felicitous phrase, the "common law with its entrancing vision of a pot of gold." 177 It does seem that the objections of trade union leaders can be met by instituting some of the alternatives posed in the White Paper. The removal of the limit for the first four weeks of compensation could be carried out relatively easily as the Select Committee recognized in its Report. A schedule combining pain and suffering and loss of enjoyment of life could be included in the scheme although it might be rather expensive. Whether or not all the legal advisers of the various unions would find such proposals acceptable is not clear and these lawyers have obviously helped persuade the trade union officials to oppose the recommendations of the Royal Commission. No doubt a number have done so sincerely, yet the fact has to be faced that personal injury lawyers stand to lose a great deal of business from implementation of the scheme.

The trade unions regarded the report from rather too myopic a view. They considered the worker only when he was at work. The Woodhouse recommendations on the other hand comprised "twenty-four hour insurance for every member of the work force, and the house-

\footnotetext{
174 Automobile Accident Insurance Act, R.S.S. 1965, c. 409

173 New Zealand Federation of Labour, Submission to Parliamentary Select Committee on Personal Injury (1970). Barrer. Submission on behalf of seventeen unions in the District of Canterbury to Parliamentary Select Com. mittee on Personal Injury (1970); Amalgamated Society of Railways Servants, the New Zealand Locomotive Engineers, Firemen and Cleaners Association, the New Zealand Railway Tradesmens Association, Submissions to the Parliamentary Select Committee on Personal Injury (1970); McClelland, Submissions on behalf of fifteen Canterbury district trade unions to Parliamentary Select Committee on Personal Injury (1970).

176 Federation of Labour Submissions, supra, n. 175 at 1.

127 Mathieson, Report of Royal Commssion for Personal Injury in New Zealand, (1968) 31 Mod. L. Rev. 544 at 546.
} 
wives who sustain them."178 One might have expected trade unions in this day and age to give some consideration to their members as humans in a total societal environment not just as men at work.

\section{c. Submissions from the Legal Profession}

The New Zealand Law Society admitted at the outset "that there is such a wide diversity of opinion amongst members of the legal profession on this complex social and economic issue that the Council of the New Zealand Law Society is unable to express a view embracing the whole of the profession as to the introduction of absolute liability for personal injury."179 Nevertheless, the Society stated that it was the unanimous view of members that if a scheme such as proposed in the Woodhouse Report was to be adopted "there are certain fundamental changes or alterations to the scheme as proposed which are not only desirable but are necessary before the legal profession would subscribe to the all embracing Scheme. . ."180 The Society thought that in the first instance the scheme should be restricted to accidents occuring during the course of a worker's employment. There were, in the Society's view, three reasons for this. First, the Royal Commission had been directed to inquire into work connected accidents. Second, the Ontario scheme which the Commission had found so persuasive was restricted to work accidents. Third, the costs for the comprehensive scheme were "really nothing better than a calculated guess."181 However, the Society produced no evidence to show why the Commission's costing and that of the Government's White Paper were to be impugned. The argument that the scheme ought to be restricted to work connected accidents because that was all the Royal Commission was asked to report on is a technical argument based on the construction of words which is quite unconvincing as a criticism of the Commission's logic. Confining a no fault scheme to work accidents would be productive of a fresh set of discriminations between the various classes of the victims of accident quite as virulent as those which already exist.

The Society went on to argue that the administration of the scheme must be entirely independent from any existing Department of State. The Society also made a number of suggestions about the improvement of the levels of compensation recommended by the Royal Commission. In the Society's view compensation for permanent partial disability should be paid on the basis of 80 percent of future economic loss and that there should also be payments under a schedule combining pain and suffering and loss of enjoyment of life. These suggestions found favour with the Select Committee. The Society also made some arguments about the procedure for review of claim determinations and permitting appeals to the newly created Administrative Division of the Supreme Court. ${ }^{182}$

It is apparent that the Woodhouse Recommendations caused a sharp division of opinion among members of the New Zealand legal profession. ${ }^{183}$ The Manawatu District Law Society was dissatisfied with

\footnotetext{
178 Compensation for Personal Injury in New Zealand, supra, n. 7 at para. 18.

179 New Zealand Law Society Submissions, supra, n. 158 at 1.

180 Id. at 2.

181 Id, at 3 .

1 toz Cf., White Paper, supra, n. 9 at 125-126.

123 The New Zealand Law Society, Newsletter 22, Dissentient Views, at 10 (1970).
} 
the New Zealand Society's submissions and made independent submissions stating that it was totally opposed to the recommendations of the Woodhouse Report. ${ }^{184}$ This action caused some discussion in the Council of the New Zealand Law Society, which was itself split on the issue. ${ }^{185}$ In the end the Council decided against making a rule to muzzle the District Societies in such circumstances. In the past the New Zealand Law Society has been a very effective pressure group on matters of concern to legal practitioners and solidarity has been a big element in its effectiveness. The fact that the legal profession had been seen publicly split on the desirability of implementing the provisions of the Woodhouse Report, made the politicians feel much freer in coming to their own conclusions on the adequacy of present arrangements and the nature of the scheme to replace them.

Some individual practitioners also made submissions. A group of seven Hamilton practitioners suggested that subject to certain reforms the present system be retained. ${ }^{186}$ An individual practitioner from Manawatu took a similar position. ${ }^{187}$ Two academic lawyers from the Victoria University of Wellington made submissions endorsing the Commission's Recommendations subject to minor modifications. ${ }^{188}$ The writer sent a lengthy submission from the United States analysing other submissions, and endorsing the main principles of the Royal Commission's Report. ${ }^{189}$

\section{d. Submissions of the Automobile Association}

In its submissions to the Parliamentary Select Committee the New Zealand Automobile Association Inc. described itself as the national secretariat for the 15 constituent Automobile Associations in New Zealand and a "policy making body on motoring matters of national interest."190 The submissions are notable for a hearty attempt to justify the fault system. At the forefront of this defence is the idea of personal responsibility: "it would be a retrograde step to abandon the fault principle with its emphasis on personal responsibility."191 That argument is, of course, subject to all the infirmities of a similar one made by $\mathrm{Mr}$. Laycraft and criticised earlier in this paper. However, sensing that change was in the wind the Association sought to bend the rules of fault a little. This the Association would accomplish by abolishing the jury and espousing a concept called "reverse risk" under which the burden of proof would lie with the defendant.

The Association did not appear to appreciate, however, that this proposal cuts right across the justification advanced for it-personal responsiblity. If negligence is presumed, the person against whom it is presumed will be held liable unless he can show he was not negligent. Yet he may not have been negligent in fact, even though he cannot marshal sufficient evidence to prove it. Such a presumption is likeIy,

\footnotetext{
184 Rowe (President, Manawatu District Law Society) Submission to Parliamentary Select Committee on Personal Injury, (1970); See Nelson Evening Mail, February 22, 1970, at 2, col. 3.

16s New Zealand Law Society Newsletter, supra, n. 183 at 11.

186 A Group of Hamilton Solicitors, Submissions to Parliamentary Select Committee on Personal Injury (1970).

187 Lusk, Submissions to Parliamentary Select Committee on Personal Injury (1970).

188 Mathieson, Submissions to Parliamentary Select Committee on Personal Injury (1970); Szakats, Submissions to Parliamentary Select Committee on Personal Injury (1970).

189 Palmer, Submissions to Select Committee, supra, n. 172.

190 Automobile Association, Inc., Submissions to Parliamentary Select Committee on Personal Injury 1 (1970).

19i Id. at 14.
} 
therefore, to irritate and demoralize those who take personal responsibility seriously.

The Automobile Association found itself in a position of some embarrassment. For many years the Association has been writing a large amount of motor insurance through the North Island Motor Union and the South Island Motor Union which are wholly owned by the Automobile Associations. Now it seems that the Association is more interested in retaining the personal injury side of its insurance business than it is in looking to the real interests of its membership. No attempt seems to have been made by the Association to ascertain the views of its very large membership.

\section{e. Other Pressure Groups}

As with so many suggested changes the protective pressure groups were out in force and there were few major groups acting as promotional pressure groups for the Royal Commission scheme. However, some of the groups which made submissions to the Select Committee gave unqualified support to the Commission's proposals. The New Zealand Service Association was the most important of these. ${ }^{192} \mathrm{New}$ Zealand has an unusually high proportion of public servants in its work force and their 'trade union' has traditionally been a vocal and progressive pressure group. The various organizations of medical practitioners also saw great good in abolishing the common law action. ${ }^{193}$ A number of other miscellaneous organizations found the scheme to their liking. 194

Some aspects of the Commission's proposals which had considerable political appeal have remained dormant. Housewives who are injured around the home, or indeed anywhere, under the Commission's proposals would be compensated. The National Council of Women made submissions to the Select Committee saying "as would seem natural" there was unanimous approval in that organization for the inclusion of housewives in a compensation scheme. ${ }^{95}$ Yet the appeal of the scheme to this previously unprotected group has yet to make a real impact. The Select Committee left the housewives out of its recommendations. The Government may be running political risks in leaving out of the scheme housewives who are injured in the home.

Another considerable area of support for the Report came from the Government's advisers. The Interdepartmental Committee of top public servants had intensively studied and evaluated the Royal Commission's Report and was convinced that it was both feasible and desirable. The advice the appropriate Ministers received from their Permanent Heads was almost certainly in favour of implementation. New Zealand has a career public service organized on the basis of merit and the upper echelons are very influential in policy making.

192 New Zealand Public Service Association, Submissions to Parliamentary Select Committee on Personal Injury (1970).

10s Medical Association of New Zealand, Submissions to Parliamentary Select Committee on Personal Injury (1970); New Zealand Orthopaedic Association, Submissions to Parliamentary Select Committee on Personal Injury (1970); Royal Australasian College of Surgeons, Submissions to Parliamentary Select Committee on Personal Injury (1970).

194 Agricultural Pilots Association, Submissions to Parliamentary Select Committee on Personal Injury (1970); New Zealand Master Builders Federation, Submissions to Parliamentary Select Committee on Personal Injury (1970); New Zealand Shipowners' Protection and Indemnity Association, Submissions to Parliamentary Select Committee on Personal Injury (1970).

19s The Evening Post, May 1, 1970, at 10, col. 2. 
[VOL. IX

\section{Report of the Select Committee}

The Report of the Select Committee ${ }^{196}$ which is 83 pages in length, was tabled in the House of Representatives on November 12, 1970.197 It bears the marks of political compromise and it appears that some of the document had been drafted before the politicians had hammered out a position on some of the vital issues. Although the Report is a significant endorsement of the Royal Commission's approach, it is plain from reading between the lines that it was touch and go whether the Government would go along with the Commission. The Government was obviously tempted to go only as far as a no-fault scheme for work injuries and so avoid serious difficulties with the insurance companies.

What prompted the Government's decision to go for the high ground? It is fairly clear that the Select Committee was not a free agent. There is reason to suggest that the Committee, or at least the Government members of it, were not willing to reach any conclusions until they heard the word from Cabinet. Indeed this would be a very natural reaction. It would be no advantage for a group of back benchers to make recommendations publicly only to be left high and dry by Cabinet. Such a spectacle would be politically embarrassing all around. The key figure in determining the direction taken by the Committee must have been the only member of Cabinet on the Committee, the Minister of Justice, the Hon. D. J. Riddiford, who is also Associate Minister of Labour and a lawyer. The Committee would have been prone to go no further than Mr. Riddiford wished. Mr. Riddiford must have decided to let the Committee come to grips with the real issues. He must also have been a vital figure in influencing first Cabinet and then Government caucus to opt for root and branch change.

A number of factors must have persuaded both Cabinet and Government caucus to go as far as they did. First in importance was the sheer logic of the Commission's proposals, the eminence of the Commissioners and the very persuasive manner in which the recommendations were tailored to New Zealand conditions. Second, opponents of the scheme found it very difficult to find convincing arguments to counter the Commission's logic. Almost every group making submissions to the Select Committee conceded that the existing arrangements had serious weaknesses, although there were deep divisions about the nature of the replacement. Third, the thorough investigation by Government officials had demonstrated the feasibility of the scheme and they were in favour of its implementation. Fourth, no new expenditures of tax revenues were necessary to implement the scheme. Fifth, by adopting the scheme the Government would be able to claim that it had been responsible for perhaps the most significant social reform in New Zealand for thirty years. The Labour Opposition had espoused the scheme and failure to act positively would likely have made the Commission's Report a major political issue in the general election campaign of 1972 . Sixth, by making relatively small adjustments to the scheme it was possible to blunt some of the objections of the more important opponents of the scheme, especially the trade unions and insurance companies, as will appear shortly.

198 Report of Select Committee on Compensation for Personal Injury in New Zealand-laid on the table of the House of Representatives (1970).

197 The New Zealand Herald, 13 November 1970, at 1, col. 1. 
Before the Report of the Select Committee was laid on the table of the House, it had obviously been discussed by Government caucus and Cabinet. The same day the Report was tabled the Acting Minister of Labour announced to the House that the Government had "approved in principle" the recommendations of the Committee. A Cabinet Committee had been set up to supervise the drafting of legislation. The Government committed itself to introducing legislation in 1971. 198

No members of the Committee wrote dissents to the Report and it is clear that except for detail the matter has become a bi-partisan one between the political parties. However, in the parliamentary debate on the Committee's Report the four opposition members of the Committee made it clear that they regarded implementation as long overdue. The Chairman of the Select Committee, Mr. G. F. Gair, commented on the "complete absence of political undertones in the committee hearings" and the "welcome measure of general agreements on key issues."200 In the debate a Government member of the Committee, Sir Leslie Munro, expressed reservations concerning the abolition of the fault concept, but he appears to have had no support from other members. ${ }^{201}$ Dr. A. M. Finlay, the opposition's chief legal spokesman, was also on the Committee and he endorsed the report, chiding the Government for its delay in implementing the Royal Commission's scheme.

In general, the approach of the Committee was one of overall approval for the Royal Commission's Report, although friends of the Commission would criticise the Committee for not going far enough. ${ }^{202}$ The Parliamentary Committee agreed "with nearly all of the strictures made by the Royal Commission which concluded that the[common law] action is increasingly unable to grapple with the present needs of society and that something better should be found."203 The Committee recommended that for all injuries within the coverage of the scheme the right to sue for damages be abolished.

The coverage of the new scheme will be less than that recommended by the Royal Commission, but not by very much. Two new compensation schemes to be introduced will be kept financially separate although they will be administered by the same Authority. The Authority will be the independent body with wide responsibilities envisaged by the Commission. An earners' scheme will cover employers, employees and the self-employed for all accidents whether at work or not. ${ }^{204}$ There will be a road accident scheme with identical benefits for all victims of accidents on the road involving a motor vehicle. The Committee explained the more modest coverage of its proposal by saying that it was doubtful as to the practicability of compensation for non-earners not injured on the road, having heard submissions that costs would not be easy to control. The Committee decided that the situation of non-earners could

202 We endorse strongly what the Royal Commission has said on the importance-in economic terms as well as humanitarian - of seeing that the injured are rehabilitated quickly. We agree with the Commission's general attitude to compensation for the injured and to other aspects of their rehabilitation. We agree that the families of those killed in accidents should be adequately compensated for the loss of the bread winner. Finally we agree that efforts to prevent accidents should be given the highest priority. Report of Select Committee, supra, n. 196 at 13.

203 Id. at 14.

200 Id. at 11 .
} 
best be dealt with by the Royal Commission on Social Security which is deliberating. The Committee had discussions with the Royal Commission on Social Security to avoid duplicating its work and trespassing on its territory. 205

Compensation under the scheme will be made available "on an absolute liability basis."206 The injured person will be eligible for compensation on obtaining a medical certificate stating that the disability was caused by accident. Compensation will be in the form of periodic payments, except in exceptional circumstances. The basis upon which compensation will be assessed differs from that proposed by the Royal Commission. Compensation will fall into three classes:

(1) Income maintenance-compensation replacing a loss of earnings to meet the expenditures of ordinary living,

(2) In permanent injury cases only, compensation for non-economic loss, and

(3) Compensation for various expenses incurred as a result of disablement.

The rate of compensation for income maintenance was fixed at 80 percent of premium earnings before tax and the compensation itself will be taxed at source. The maximum compensation before tax for those suffering a total loss of earnings will be the equivalent of $\$(N . Z)$.120 gross in 1967 money values. The minimum will be $\$($ N.Z.)30 per week plus dependants' allowances of $\$(\mathbf{N} . Z$.)3 per week for a wife and $\$(N . Z$.) 1.50 for each child so long as the total payment does not exceed 9 percent of previous tax paid earnings. For non-fatal accidents, payments are to begin eight days after the accident. ${ }^{207}$ These minima are considerably more generous than those recommended by the Commission. They are obviously designed to meet trade union criticisms that no-one should be worse off than before.

On the manner of assessing compensation for permanent partial and permanent total disability the Committee recommended an important change from the Commission's proposals. In the Committee's view a schedule should not be used. Rather "compensation for both partial and total disablement should be based entirely on an estimate of loss of earnings." 208 The Committee's aim was to ensure that the compensation paid reflected the actual economic loss due to the particular injury taking into account the injured person's occupation. Under its proposal "it will be quite certain that greater economic loss to, say, a fitter and turner who loses an arm as compared with a bank clerk who loses his non-writing arm, will be properly recognized."209

There are some serious difficulties with this suggestion and it may not survive the scrutiny of Government officials in the drafting of the legislation. First, since the Committee's approach requires an individual assessment in every case the administrative expenses are

\footnotetext{
${ }^{205}$ Id. at $21-22$

200 Id. at 12

${ }^{207}$ Id. at 46-47.

208 Id. at 38.

209 Id.
} 
likely to be increased significantly. Secondly, a claimant who knows that his compensation for loss of earnings would depend on his ability to demonstrate economic loss will be inclined to magnify his complaints, delay going back to work and even avoid earnings which could diminish his compensation in the future. The method proposed by the Committee could be a serious obstacle to rehabilitation.

Compensation for non-economic loss is limited to "the order of $\$ 10,000$ or so." 210 A schedule of minimum payments will be used, with the Authority having discretion to depart from it.

The third category of compensation involves such things as funeral expenses, medical expenses not paid for by the state, travel costs incurred for members of the family to visit an injured person in hospital, and the cost of assistance for a disabled housewife or mother. Compensation rates are to be reviewed at frequent intervals, perhaps annually, in order to keep pace with changes in the cost of living. Adjustments are to be made on some index linked more closely to movements in wage levels than the consumers' price index.

It was in the sphere of administration that the Parliamentary Committee demonstrated political strategy of a high order. On the one hand the Government faced an insurance industry which stood to lose a great deal of business by implementation of the Commission's proposals. On the other hand it faced the prospect of adding to the enormous bureaucracy of the Social Security Department in New Zealand, a prospect which made even some of the Commission's allies restive. The Committee reached a compromise. It recognized the essential weaknesses of private enterprise in the personal injury business. A commercial insurer cannot "but keep in mind that each compensation payment diminishes the profits", the Report says. ${ }^{211}$ The danger of commercial interest conflicting with public interest was expressed. On the other hand the Committee acknowledged that the insurance industry had much expertise and many facilities for handling personal injury claims. The Committee recommended that the insurance companies be allowed to act as agents for the authority in paying claims, subject to the Authority's direction on the principles and methods of administration. ${ }^{212}$ The companies could also act as agents for the Authority in collecting premiums from employers for the earner's scheme. Recompense for the companies would be in the form of a scale fee and the cost would not be much different than if a public authority did the whole operation. The insurance companies have not agreed to this arrangement at the time of writing but it seems that they will have little alternative. As the Report states "... the Insurance Industry Committee was confident that the industry controls its administration efficiently. If this confidence is well-founded,

$210 \mathrm{Id}$. at 48 .

211 Id. at 24.

212 The following arrangements were suggested by the Committee:

(a) Prior to the beginning of a financial period, the authority should estimate the funds required for all its purposes and set premium rates accordingly. Then the levies would be collected by the appropriate agency. Each agency would be entitled to deduct authorized fees from the amounts collected. We refer in paragraph 63 to some of the considerations about the charges for collecting premiums for the earners' scheme.

(b) Upon the collection of levies, the authority should allow each company custody of money sufficient to meet claims and administration costs for a short but reasonable period-perhaps 6 months. Further funds should be advanced as required. Upon settlement of the initial business of a claim, the company should be entitled to draw a fee from the moneys held for the work done. Report of the Select Committee, supra, n. 196 at 54 . 
the industry will adapt itself to meet any challenges put before it by the new authority."213

On the financing of the scheme the Committee followed the approach of the Royal Commission, but adopted the White Paper's suggestion of differential premiums. It also suggested that research might be undertaken to determine whether drivers with bad accident records and convictions for driving offences should be required to pay higher premiums. The Committee was adamant that general taxation ought not to be resorted to in order to finance the scheme. If more finance was needed it must be raised by increasing the levies on employers, the self-employed and motorists.

The Committee's Report was well received by the newspapers. All editorials on the matter praised the approach of the Committee and the only criticism came from one paper which felt that the Committee should have gone all the way with the Royal Commission..$^{214}$

\section{Afterword}

It took a long time for the seeds sown by the Royal Commission in 1967 to germinate. But at last they have taken hold. In 1971 New Zealand will get the most far reaching and comprehensive compensation scheme for personal injury in the common law world. Although there are many details to be settled, the main outline of the scheme can now be discerned.

Because of the number of influential groups opposed to the Report and clearly adversely affected by it, the National Government proceeded cautiously. The issue was fed into the parliamentary machinery very gently, first through Government caucus and then by means of a Select Committee. Now that Cabinet is committed to change and the Opposition agrees, retreat is impossible. There is still some room left for political maneuver. The influence of pressure groups is at its most effective in dealing with Ministers of the Crown. Affected groups will probably not give up the fight altogether with the publication of the Select Committee's report. But the main battle is over. The next chapter in New Zealand's social development will be the Report of the new Royal Commission on the welfare system. 